\title{
La encomienda de gestión como instrumento racionalizador del ejercicio de las competencias administrativas
}

\author{
Antonio José Sánchez Sáez \\ Profesor Ayudante de Derecho Administrativo \\ de la Universidad de Sevilla
}

\section{INTRODUCCIÓN}

Más que en ninguna otra rama del Derecho, en nuestra disciplina se cumple la inexorable teoría de Nietzsche sobre el eterno retorno. El avance vertiginoso de la realidad hace que el Derecho Administrativo tenga que dedicar gran parte de sus esfuerzos a explorar nuevos territorios, los cuales, apenas hoIlados, pierden ya interés para la doctrina. En esa permanente obsolescencia, en esa huida hacia delante, a la Administración se le van cayendo objetos por el camino, que tiene que recoger de vez en cuando para poder seguir avanzando. Esta "vieja maldición" se manifiesta en unas materias más que en otras, y así ocurre con la propia de la organización administrativa, tan estudiada como olvidada, y objeto de permanente mala conciencia para los autores del Derecho Público.

Quizás por ello, la regulación del ejercicio de las competencias administrativas en España se ha caracterizado siempre por la voluntad expresa de permitir un cierto grado de flexibilidad que pueda corregir, en cierta medida, la rigidez del reparto de competencias establecido en la Constitución, con la intención de tolerar su adaptación a las cambiantes circunstancias que puedan suscitarse en cada momento histórico. Este fenómeno se exterioriza, entre otras cosas, en la importancia que el Ordenamiento jurídico concede a los principios de interrelación voluntaria de las Administraciones, como los de cooperación, colaboración, descentralización, subsidiariedad, auxilio recíproco, etc. o en la indefinición formal de las competencias de las Entidades Locales. La propia Constitución y el bloque normativo de atribución de las competencias administrativas incluyen suficientes cláusulas de movilización de las competencias como para superar el entendimiento de las relaciones interad- 
ministrativas basado en el principio de separación de competencias y pasar a una concepción consensuada de la actividad interadministrativa que PÉREZ MORENO denomina sugerentemente como "Sistema de Administraciones Públicas", que llama a una cierta ductilidad relativa en el ejercicio de las mismas, basada en el principio de eficacia.

La encomienda de gestión, como el resto de las instituciones del Capítulo I del Título II de la LRJAPyPAC, nació con esa común finalidad flexibilizadora del principio de irrenunciabilidad de las competencias y tiene en los principios de cooperación y colaboración su génesis y su sustrato mediato ${ }^{1}$.

La Ley 30/ 1.992, de 26 de noviembre, de Régimen Jurídico de las Administraciones Públicas y del Procedimiento Administrativo Común (LRJAPyPAC) reguló con carácter básico para todas las Administraciones Públicas la denominada Encomienda de Gestión, recogida en su art. 15. Se trata de una institución que, como tantas otras en nuestra disciplina, es deudora del Derecho Local, en cuya Ley Reguladora se había insertado (arts. 27, 37, 106.30 Disp. Final 5a $L R B R L$ ) como forma de delegación de competencias desde el Estado o las Comunidades Autónomas a las Entidades Locales, o de encargo 0 auxilio de los Municipios a las Diputaciones para la gestión, liquidación, inspección y recaudación de tributos. Al Legislador estatal le pareció bien incorporar la figura al régimen común de ejercicio de las competencias de las Administraciones, y, aunque su impacto en nuestra disciplina no ha sido tan notorio como otros preceptos de la Ley, es cierto que ha sido normalmente aplicada en todo el Estado, si bien incurriendo en no pocas dudas e incorrecciones que la escasa jurisprudencia recaída hasta el momento no ha acertado a conjurar. En este estudio intentaremos aclarar algo sobre su presupuesto de hecho, su objeto, su régimen jurídico y su naturaleza, diferenciándola de otras figuras cercanas como la delegación, para, finalmente, distinguir brevemente su uso a escala estatal y autonómica del específico estatuto jurídico del que goza a nivel local.

\footnotetext{
${ }^{1}$ Por encima del concreto ejercicio administrativo de las competencias, a nivel constitucional no solamente el principio de cooperación sino incluso el de coordinación están orientados a "flexibilizar y prevenir disfunciones derivadas del propio sistema de distribución de competencias, aunque sin alterar en ninguno de los casos la titularidad y el ejercicio de las competencias propias de los entes en relación" (Fdto. Jco. 20 de la STC 214/ 1.989, de 21 de diciembre). El principio de colaboración, como sabemos, se halla "implícito en la propia esencia de la forma de organización territorial del Estado que se implanta en la Constitución" (Fdto. Jco. 14a STC 18/ 1.982, de 4 de mayo y Fdto. Jco. 7ạ STC 233/ 1.999, de 13 de diciembre).
} 
Pero, antes de nada, dejemos constancia escrita del tenor literal del art. 15 LRJAPyPAC, que, por cierto, no ha sufrido modificaciones desde 1.992:

\section{Artículo 15. Encomienda de gestión}

1. La realización de actividades de carácter material, técnico o de servicios de la competencia de los órganos administrativos o de las Entidades de derecho público podrá ser en comendada a otros órganos 0 Entidades de la misma o de distinta Administración, por razon es de eficacia o cuando no se posean los medios técnicos idóneos para su desempeño.

2. La encomienda de gestión no supone cesión de titularidad de la competencia ni delos elementos sustantivos de su ejercicio, sien do responsabilidad del órgano o Entidad en comen dan te dictar cuantos actos o resolu ciones de carácter ju rídico den soporte 0 en los que se integre la con creta actividad material objeto de en comien da.

3. La en comienda de gestión en tre órgan os administrativos o Entidades de derecho público perten ecientes a la misma Administración deberá formalizarse en los términos que establezca su normativa propia y, en su defecto, por acuerdo expreso de los órganos o Entidades encomienda de gestión y su resolución deberá ser publicado, para su eficacia en el Diario oficial correspondiente.

Cada Administración podrá regular los requisitos necesarios para la validez de tales acuerdos queincluirán, al menos, expresa mención de la actividad 0 actividades a las que afecten, el plazo devigen cia y la natu raleza y alcance de la gestión en comendada. 4. Cuando la encomienda de gestión se realice entre órgan os y Entidades de distintas Administraciones se formalizará mediante firma del correspondiente conve nio entre ellas, salvo en el supuesto de la gestión ordinaria de los servicios de las Comunidades A utón omas por las Diputaciones Provinciales o en su caso Cabildos o Consejos insulares, que se regirá por la legislación de Régimen Local.

5. El régimen jurídico de la en comien da de gestión que se regula en este artícu lo no será deaplicación cuando la realización de las actividades enumeradas en el apartado primero haya de recaer sobre personas físicas o jurídicas sujetas a derecho privado, ajustándose entonces, en lo que proceda, a la legislación correspondiente de contratos del Estado, sin que puedan encomen darse a personas o Entidades de esta natu raleza actividades que, según la legislación vigen te, hayan de realizarse con sujeción al derecho administrativo.

\section{PRESUPUESTO DE HECHO DE LA ENCOMIENDA DE GES- TIÓN}

Aparte el prefijo -en, de origen castellano medieval, la etimología de la palabra "encomienda" es claramente latina: commen dare (cum-man do), significa 
literalmente "mandar a alguien hacer algo propio". La misma expresión podía entenderse también como "confiar en alguien", lo que denota el grado de proximidad o afinidad existente entre el que encomendaba y el encomendado. Así, los romanos "comendaban" a sus sirvientes la realización de recados, los Generales "comendaban" a sus centuriones la ejecución de la estrategia en la guerra o los ciudadanos "comendaban" a los dioses sus plegarias y peticiones. Como veremos, este sentido de "fiducia" o confianza en el encomendado para hacer algo sigue permaneciendo en el significado técnico-jurídico del término, ya que lo que se confía o encomienda suele ser un mandato o deseo propio del encomendante, y esa misma confianza permite al encomendado rechazar la encomienda 0 , al menos, negociar sus términos.

Con este antecedente, el presupuesto de hecho de la encomienda de gestión se encuentra en el apdo. 10 del art 15. En breves palabras, consiste en la posibilidad que tiene un órgano o Entidad de derecho público de una Administración de encargar la realización de actividades de carácter material, técnico o de servicios a otros órganos o Entidades de la misma o de distinta Administración, porque entiende que sólo con ello se podrá cumplir aquella actividad (porque carezca de los medios apropiados para llevarla a cabo) o porque considera que así se podrá satisfacer mejor la necesidad pública que motiva la atribución de la competencia ( porque sabe que el encomendado, por cualquier motivo estrictamente objetivo y jurídico, es más eficaz en su realización o reconoce que los medios de que dispone no son los adecuados para ello). La parte que realiza el encargo se denomina encomendante, y encomendado o encomendero la que lo realiza.

\section{Razones que pueden mover a la encomienda: la encomienda como elemento racio- nalizador del ejercicio de las competencias administrativas y la existencia de una "dis- crecionalidad interadministrativa" en la atribución competencial}

El apdo. 10 del art. 15 LRJAPyPAC establece que son las razones de eficacia o de ausencia de medios adecuados las que pueden motivar la encomienda. Subyace en esa idea el entendimiento de todas las Administraciones que integran el sistema administrativo español como un todo funcional - ya que no orgánico - dirigido a la satisfacción de una misma finalidad: los intereses generales y la calidad con que éstos se prestan. Según esto, la encomienda puede producirse indistintamente, es decir, entre diferentes Administraciones ( $y$, entre ellas, aunque lo normal será que se produzca desde una Administración "superior" a otra "inferior", también puede darse el caso opuesto²) 0, dentro

${ }^{2}$ Los Departamentos de Presidencia e Interior de la Comunidad Foral de Navarra encomendaron al Ministerio del Interior la realización de las actividades técnica relacionadas con la com- 
de una misma Administración, desde un órgano administrativo superior a otro inferior, de uno inferior a otro superior o entre órganos no jerarquizados. Esto quiere decir que lo importante, realmente, no es qué Administración ejerce la competencia sino que la ejerza quien la puede ejercer mejor, con mayor eficacia.

La eficacia es un concepto resbaladizo que, en materia de encomienda de gestión, debe suponer la ponderación de los diferentes parámetros de bondad que puedan concurrir en el ejercicio de la competencia: los medios de que disponga el órgano, el tiempo que tarde en prestar el servicio, la calidad con que lo preste, la cercanía al ciudadano del órgano administrativo, la mayor o menor participación ciudadana en la actividad a realizar, etc. Comoquiera que el mandato de eficacia es indeterminado, su concreción debería realizarse conjuntamente por todas las Administraciones con intereses sobre la parcela de interés público a la que la competencia afecta ( y no sólo por una o dos Administraciones determinadas), fueran o no inicialmente competentes para llevar a cabo la actividad material o formal de que se trate.

Es por ello por lo que postulamos que en la materia de la organización administrativa debería existir siempre, antes del ejercicio de cualquier competencia, una primera fase de reflexión sobre quién debe ejercerla, que conforma una potestad de atribución conjunta que podríamos denominar de "discrecionalidad interadministrativa" (o interorgánica, si las partes negociadoras son órganos de una misma Administración), cuyo marco de libertad de actuación quedaría limitado por las normas de atribución de competencias, y cuyos elementos reglados vendrían concretados por los criterios de eficacia que cada Administración u órgano ostente y los principios básicos de las relaciones administrativas del art. 4 LRJAPyPAC, y que consistiría en la ponderación conjunta por parte de todas las Administraciones implicadas (y no ya exclusivamente de la Administración que tenga atribuida la competencia) de los intereses ajenos en el ejercicio de las competencias propias ( ex art. 4.1,b) LRJAPyPAC). Tras esa primera fase, la Administración competente estará ya en condiciones de atribuir la competencia a ejercer a la Administración más capacitada para el caso concreto. En ese sentido entiendo que debe jugar la interpretación de la eficacia que exige la encomienda de gestión en el art. 15.1 de la LRJAPyPAC, sólo que en este caso la interpretación de la discrecionali-

petencia en materia de juegos propia de la Comunidad, en convenio suscrito entre ambas y plasmado en Resolución de la Secretaría General Técnica del Ministerio del Interior de 14 de julio de 1.998 (B.O.E. de 31 de julio). 
dad interadministrativa o interorgánica de la atribución competencial queda al arbitrio de las partes que integran el convenio de encomienda ( y no a todas las potencialmente susceptibles de prestar la actividad material técnica o de servicios precisa), y es precisamente ésta la razón por la que la encomienda atiende más a evitar la ineficacia propia que a buscar a la Administración u órgano más eficaz posible 3 .

Obviamente, las razones válidamente alegables de eficacia o ineficacia que pueden dar lugar a una encomienda de gestión pueden concitarse por circunstancias sobrevenidas de una manera sorpresiva o por la ineficacia crónica del órgano o entidad de que se trata. En el primer caso estaríamos hablando de un aumento subrepticio y desproporcionado de las competencias propias de un órgano o entidad, ya sean definitivas (motivadas por la atribución de una competencia por una ley o reglamento 4 ), o temporales y puntuales (lo que podríamos denominar más bien cometidos), consecuencia de órdenes o actos administrativos de órganos superiores. Por el contrario, otras veces, la ineficacia puede deberse a circunstancias progresivas, como recortes paulatinos de personal, de medios económicos o técnicos.

\footnotetext{
${ }^{3}$ Aunque la idea de la discrecionalidad inter o panadministrativa me parece sugestiva, se topa de bruces con la misma dificultad que intenta solucionar, ya que parece difícil poder encontrar un instrumento capaz de realizarla de manera eficaz, a través del cual todas las Administraciones ( $y$ dentro de ellas, todos sus órganos) puedan negociar en condiciones de igualdad la atribución de una competencia formal o material concreta a la Administración ( y órgano) más adecuado para ejercerla. Los convenios pueden ser la solución menos mala al respecto, y de ello nos dan ejemplo los arts. 6 y 15 de la LRJAPyPAC o la Disp. Adic. 5a LRBRL, pero su praxis para este fin requeriría, para salvaguardar las tentaciones y abusos de posición inherentes a toda negociación, un marco legislativo estatal nuevo y adecuado para ello. En ese sentido cabría entender la cita de la ST C 214/ 1.989, de 21 de diciembre, cuando habla de la cooperación como de una especie de "coordinación voluntaria". 0 tra solución para plasmar esa potestad discrecional interadministrativa de atribución de competencias sería la creación de órganos de colaboración interadministrativos, tal y como dispone el art. $58 \mathrm{LRBRL}$, y como también ha refrendado el recientemente aprobado Proyecto de Ley sobre Medidas para la Modernización del Gobierno Local, que ha añadido a la LRBRL un nuevo art. 120 bis en el que se viene a exhortar al Estado a que colabore con las CC.AA. con el fin de crear órganos de cooperación conjuntos en materia de régimen local, tanto bajo la forma jurídica de Conferencia Sectorial como de otra naturaleza, de acuerdo con lo dispuesto en el artículo 5 de la LRJAPyPAC.

${ }^{4}$ Así, el art. 15 y la Disp. Transit. 15a de Ley 30/ 1.984, de 2 de agosto, de Medidas para la Reforma de la Administración Pública, motivaron la convocatoria de pruebas selectivas para el ingreso en la Escala Técnica de Gestión de Organismos Autónomos (grupo A), en la Escala Administrativa de Organismos Autónomos (grupo C) y en la Escala Auxiliar de Organismos Autónomos ( grupo D), cuya gestión, por razones de eficacia, la Secretaría de Estado para la Administración Pública encargó al I.N.E.M. Vid. Resolución de la Subsecretaría del Ministerio de la Presidencia de 23 de diciembre de 1.998 (B.O.E. de 5 de enero de 1.999).
} 
En condiciones dotacionales o de cualificación parejas, la mayor o menor eficacia en la prestación de la actividad encomendada no debiera depender de la diligencia del personal que integra el órgano encomendado o de la percepción subjetiva que el encomendante tenga de la calidad prestacional del mismo, sino de datos objetivos derivados de la mayor capacitación técnica, económica o personal de éste, o su menor carga de trabajo en el momento de la encomienda. También podría conferirse una encomienda por razones de eficacia con base en motivos estrictamente jurídicos, derivada, por ejemplo, de los principios democrático, de descentralización o de subsidiariedad, que pueden motivar, como veremos más adelante, la encomienda de gestión del ejercicio de competencias estatales o autonómicas a Municipios y Diputaciones Provinciales, por su mayor cercanía a los intereses generales de los ciudadanos que han de ser satisfechos.

No obstante, resulta evidente que la Ley ha dejado voluntariamente indeterminado el concepto de eficacia, abriendo la puerta a cualquier consideración favorable a la encomienda que realice el encomendante. Tampoco cabe pensar que el precepto impone un especial esfuerzo de motivación al encomendante sobre las razones de eficacia que le han podido mover a encomendar, teniendo en cuenta que, en relación con la letra a) del art. 54.1 LRJAPyPAC, la encomienda permite al encomendado participar en la gestión de competencias ajenas, y que no solamente no limita derechos o intereses de éste sino que los amplía, o, cuanto menos, no los afecta. Tampoco soy partidario de un entendimiento del precepto favorable a una libérrima potestad discrecional de atribución competencial al encomendante (art. 54.1,f), ya que los principales elementos definitorios de la figura se encuentran reglados (competencia, objeto, régimen jurídico), y la única libertad que a éste le cabe en última instancia es encomendar o no la realización de una actividad propia, teniendo que atenerse a los requisitos preestablecidos en el art. 15 y en el resto del Ordenamiento jurídico si decidiera hacerlo.

A mi juicio, la eficiencia sería un criterio igualmente racional para legitimar una encomienda por razones de eficacia. Cabría así encomendar la realización de tareas a un órgano o Entidad de la misma o diferente Administración cuando éste pueda llevarla a cabo con menores costes, siempre que el nivel de calidad de la prestación fuera, cuanto menos, igual al que sería capaz de desplegar el encomendante. En cuanto al nivel de calidad habría que distinguir si la encomienda tiene por finalidad satisfacer intereses generales externos del encomendante o sus simples intereses propios. En el primer caso, al tratarse de actividades prestacionales dirigidas directamente a la ciudadanía - que son las menos, dada la vocación interna de la figura- el parámetro eco- 
nómico sólo ampararía la encomienda de gestión cuando todos los demás criterios de la prestación fueran iguales, cuanto mínimo, a los del órgano encomendante, tanto desde un punto de vista cualitativo (la forma de la prestación), como cuantitativo (los medios de la misma) o temporal (el tiempo empleado). En el segundo, las simples razones económicas podrían motivar perfectamente la encomienda a pesar de que con ello se sacrificaran las ganancias derivadas de estos otros parámetros. En su ponderación radica, como decíamos arriba, la auténtica discrecionalidad del órgano para encomendar o no el ejercicio de la competencia propia 5 .

Las razones técnicas suelen apuntarse cuando se trata de encomendar actividades propias de un órgano a una entidad pública instrumental de la misma Administración, ya que precisamente es ésta la causa de la descentralización funcional que supone la creación de este tipo de personificaciones públicas (organismos autónomos o entidades públicas empresariales). Así ocurrió en todas las encomiendas celebradas entre el Ministerio de Fomento y el Ente Gestor de Infraestructuras Ferroviarias (G.I.F.) para la realización o supervisión de obras y proyectos de líneas de tren de alta velocidad, o con la encomienda celebrada entre la Secretaría General de Medio Ambiente y el Organismo Autónomo Parques Nacionales para la administración de la Escuela Taller de Recuperación de Ecosistemas Naturales ${ }^{6}$.

También los motivos de urgencia pueden ser atendidos mediante una encomienda, pero no como justificación en sí misma sino como incidente en la

\footnotetext{
${ }^{5}$ La eficacia se encuentra además, paradójicamente, limitada por el propio principio de eficiencia, ya que no sería deseable, ni posible, la eficacia en todas y cada una de las actividades emprendidas por la Administración, sin que dejen de importar los medios empleados para conseguirlos. Esta percepción ha sido explicada por PAREJO ALFONSO, L., La eficacia como principio jurídico de la actuación de la Administración pública, en Documentación Administrativa no. 218-219, volumen titulado Administración y Constitución: el principio de eficacia, 1.989, págs. 63 a 65. En opinión de Parejo, existe una imposibilidad lógica y jurídica de conseguir la eficacia total de la actuación administrativa en su conjunto y ello debido a tres razones: la indefinición de los fines de dicha actividad (y de los intereses generales en ellos plasmados); la interdependencia de dichos fines, que hace que existan interferencias entre las distintas actuaciones a tomar, y la necesidad de proporcionalidad entre los medios y los fines de toda actuación pública (punto de encuentro entre la eficacia y la eficiencia, que asume ambas exigencias) que interdice la búsqueda de la eficacia a cualquier precio, ya sea por motivos económicos o de ablación de derechos individuales o sociales importantes. Lógicamente hablamos aquí de eficacia predicada del ámbito de todas las competencias de una Administración, no como el éxito de una puntual actuación administrativa, en que la eficacia no sólo es posible sino deseable (pág. 50).
}

${ }^{6}$ Resolución de la Secretaría General de Medio Ambiente de 15 de julio de 2.002 (B.O.E. de 30 de agosto). 
eficacia o en los medios adecuados del órgano encargado de prestar un servicio determinado?.

A fin de cuentas, dada la labilidad del concepto de eficacia y presupuesto el dato de que es el propio encomendante el que tiene que justificar su uso, podemos concluir que las encomiendas de gestión se acaban usando más por razones de oportunidad que por razones jurídicas.

\section{EI elemento subjetivo}

Obviamente, el encomendante sólo podrá encargar el ejercicio de una competencia propia, que le hubiera sido previamente atribuida. Ello no prejuzga la forma en que dicha atribución hubiera tenido lugar, ya que, aunque lo normal es encomendar la gestión de competencias originarias del encomendante (directamente atribuidas por una ley o reglamento), nada obsta a que éste la hubiera adquirido por delegación o transferencia 8 .

\footnotetext{
${ }^{7}$ Así sucedió, p. ej., en la encomienda de gestión celebrada entre los Ministerio de Exteriores y de Interior para permitir a éste la expedición de visados en la frontera, con vistas a resolver situaciones urgentes de tipo humanitario, de interés nacional o derivadas de obligaciones internacionales (Convenio de Schengen), plasmada en la Resolución de la Subsecretaría del Ministerio de la Presidencia de 4 de junio de 1.998 (B.O.E. de 11 de junio). Nótese, de todas formas, que cuando la urgencia es previsible - como es aquí el caso - y no refiere a circunstancias de fuerza mayor, no cabría hablar de urgencia en puridad de términos, sino de atribución subrepticia de competencias. Por la misma razón tampoco cabría denominar como "de urgencia" las razones alegadas por la Consejería de Educación de la Comunidad de Madrid para prorrogar la vigencia de la encomienda realizada en la Secretaría General Técnica de la misma para la tramitación de los títulos académicos y profesionales correspondientes a las enseñanzas establecidas en la LO. 1/ 1.990, LOGSE. Se trata, además, de una encomienda celebrada mediante Orden, sin convenio entre las partes por tratarse de órganos jerarquizados. Es una contradicción en términos hablar de urgencia cuando se está prorrogando una encomienda.
}

${ }^{8}$ Así, por ejemplo, el R.D. 422/ 1.988, en su Disp. Adicional. 1 a dispuso que las CC.AA. que se hubieran hecho cargo por delegación del estado de la gestión y liquidación del Impuesto General sobre las Sucesiones podían encomendar a las oficinas liquidadoras de partido, a cargo de Registradores de la Propiedad, funciones de gestión y liquidación del mismo. También lo decía el Reglamento del impuesto en su Disposición Adicional. Lo mismo ocurría en las O ficinas de Registro Hipotecario que gestionaban el ITPyAJD por encomienda de las CC.AA., previa delegación estatal, ex Disp. Adic. de la Ley 29/ 1.991.

En la encomienda de gestión recogida en la Resolución de 26 de diciembre de 2.002 del Centro Andaluz de Medicina del Deporte (BOJA de 30 de enero), la Consejería de Turismo de la Junta de Andalucía delegó en el Centro de Medicina y Deporte la realización de determinadas competencias, y éste, a su vez, encomendó a la Secretaría General Técnica de la Consejería de Turismo la realización de los actos de trámite propios de dicha competencia. 


\section{III. ÁMBITO OBJETIVO}

No parece haber muchas dudas respecto al ámbito subjetivo de la encomienda de gestión, pero, por el contrario, no queda tan claro cuál es exactamente el espacio objetivo vedado por el Legislador y al que la encomienda no podría extenderse. El art. 15 sólo permite la realización de actividades materiales o prestacionales por parte del encomendero, lo que parece querer excluir ope legis cualquier actividad formalizada o procedimentalizada que pueda tener trascendencia externa (más allá de los efectos que se produzcan entre las partes celebrantes del negocio), como el dictado de actos administrativos o el ejercicio de cualquier potestad administrativa, de suyo rodeadas de especiales garantías de publicidad y forma para los administrados. Lo que no prohíbe el art. 15 es que la actividad material encomendada pueda producir efectos externos, bien porque se trate de una actividad que se preste a los ciudadanos, bien porque, aunque se preste al encomendante, pueda redundar por su mayor eficacia en una mejora de los servicios que aquéllos reciben ${ }^{9}$.

Un ejemplo prototípico de encomienda de actividad puramente material podría ser aquélla en la que la Conselleria de Cultura, Educación y Ciencia de la Comunidad Valenciana encargó a la Conselleria de Sanidad de la misma la atención médica-sanitaria especializada a los participantes en los Juegos Deportivos de la Comunidad Valenciana ${ }^{10}$.

Obviamente, existe una amplia zona de incertidumbre cuya determinación queda, en última instancia, en manos de los órganos o Entidades que vayan a celebrar un convenio de encomienda. Sólo es trasladable el ejercicio de competencias mediante encomienda a otros órganos y Administraciones cuando dichas competencias no excedan el ámbito objetivo recogido en el art. 15.1 LRJAPyPAC, de manera que, lo que vaya más allá de ese marco necesitará de una Ley de delegación o transferencia, salvo que el órgano delegado sea una

\footnotetext{
${ }^{9}$ Así, en la encomienda de gestión celebrada entre la Secretaría Sectorial de Acción Social, Menor y Familia de la Comunidad Murciana y la Dirección General de Recursos Humanos y Organización Administrativa, recogida en la Resolución de la primera de 29 de marzo de 2.000 (BOMU de 19 de abril), ésta se comprometía a tramitar la expedición, renovación y firma de los títulos de familia numerosa, lo que acababa incidiendo positivamente en los ciudadanos de esta Comunidad Autónoma, no sólo por la mayor eficacia y agilidad de la prestación ejercida por el encomendero, sino porque éste contaba con unidades móviles para la solicitud y renovación del título, de las que carecía el encomendante.
}

10 Vid. Resolución de la Presidencia de 11 de abril de 2.000 (BOGV de 11 de mayo). 
Administración Local, en cuyo caso los arts. 27 y 37 LRBRL permiten ampliar el ámbito competencial local mediante convenios.

En principio, nada impide en el art. 15 LRJAPyPAC encomendar el ejercicio de potestades administrativas si éstas tienen un carácter eminentemente material o técnico, como podría ser la potestad de deslinde o de investigación. Esta posibilidad parece estar permitida por la cláusula de libertad de pactos del art. 4 TRLCCAAPP y así lo ha considerado también alguna doctrina11. O tras potestades que exigen para su ejercicio el dictado de actos administrativos o su formalización en un procedimiento escrito no podrían serlo, salvo que una ley así lo permitiera. Así lo ha declarado la STSJ de Castilla y León de 15 de noviembre de 2.002. Allí el Tribunal entendió que los Registradores de la Propiedad que tenían encargada la gestión y liquidación del IS y del ITPyAJD ( por parte de sendos Decretos de la Comunidad Autónoma, que llevaron a la celebración de determinados convenios de encomienda) no la ejercían en aras de una encomienda de gestión sino como delegación de competencias, ya que la atribución de la potestad sancionadora y de dictar resoluciones iba más allá de las puras actividades materiales, técnicas o de servicios.

En cuanto a la tramitación de procedimientos, en contra de los ejemplos que arroja la praxis de la figura, parece que no debiera estar incluida en la cláusula objetiva del art. 15, ya que puede provocar efectos externos que afecten a los particulares, aunque ello no haya impedido, como decimos. que en muchas ocasiones haya sido objeto de encomienda. El origen de esta incongruencia, junto con otras muchas en las que el órgano o entidad encomendante se extralimita en las funciones que encarga, puede encontrarse en la confusión entre actuaciones materiales o de servicios y actuaciones instrumentales. Claramente, se trata de cosas distintas. Si el art. 15 permitiera encomendar todas las actividades previas a la resolución final de un procedimiento, al dictado de un acto administrativo o a la aprobación de un reglamento, el margen de actuación del encomendado sería prácticamente ilimitado, y, por ello, ilegal. Sin embargo, la ambigüedad de lo que sean actividades "materiales" o de "servicios", como conceptos jurídicos indeterminados, permite al encomendante, previa sucinta motivación, encargar todo tipo de actividades sustanciales o formales, cuya validez pocas veces se ve comprometida legalmente, ya que ha sido objeto de negociación previa con el enco-

\footnotetext{
${ }^{11}$ Cfr. MARTÍN HUERTA, P., L os convenios interadministrativos, I.N.A.P., Madrid, pág. 185.
} 
mendero y que no suelen dar lugar a recurso administrativo o contencioso por parte de los administrados ${ }^{12}$.

En esa clave hermenéutica de equivalencia errónea entre "actividad material " $y$ "actividad instrumental" cabe insertar el convenio de encomienda celebrado entre el Instituto para la Reestructuración de la Minería del carbón y Desarrollo Alternativo de las Comarcas Mineras y la Subsecretaría de Economía del Ministerio de Economía para la tramitación, por parte de la Subdirección General de Recursos y Reclamaciones del Ministerio de Economía (órgano dependiente de ella), de los recursos que se interpusieran contra los actos dictados por los órganos del citado Instituto.

A veces la actividad encomendada es difícilmente justificable desde un punto de vista objetivo, ni siquiera conforme a la interpretación de "actividad material" como instrumental a que hemos aludido.

Lo que resulta innegable es que son muchos los convenios de encomienda en los que parte $o$ toda la actividad encomendada consiste expresamente en el dictado de actos administrativos, en lo que supone una clara extralimitación de la institución, que hacen al convenio, por sí mismo, nulo de pleno derecho por contradecir el procedimiento establecido en el art. 15 LRJAPyPAC, siendo también nula la resolución o acto administrativo dictado por el encomendero, por incompetencia material. Los actos administrativos en los que se plasma la actividad supuestamente material encargada a los encomenderos pueden ir desde la gestión contractual de contratos administrativos o privados, incluida la adjudicación del mismo ${ }^{13}$, a la realización de los actos de trámite necesarios para la gestión de procedimientos en materia de turismo ${ }^{14}$, la resolución de las solicitudes de suspensión automática del procedimiento

12 La tramitación de procedimientos hasta el dictado de la propuesta de resolución es un tipo muy normal de encomienda "ultra vires". Menciónese, como muestra, el convenio de encomienda celebrado entre el F.E.G.A. y diversos centros directivos para la tramitación de la ayudas derivadas del programa de mejora de la producción del aceite de oliva (en Resolución de la Presidencia del F.E.G.A. de 19 de abril de 2.002, B.O.E. de 8 de mayo), que tuvo por objeto expreso "las funciones de tramitación, previas a la resolución y pago" de las ayudas citadas, hasta "proponer la resolución de concesión o denegación del pago que corresponda".

13 Resolución de 14 de marzo de 2.003, del Instituto Madrileño del Menor y la Familia (BOCM de 8 de abril) o Resolución de 14 de marzo de 2.003, del Instituto Madrileño del Menor y la Familia (BOCM de 8 de abril).

${ }^{14}$ Resolución de 26 de diciembre de 2.002 del Centro Andaluz de Medicina del Deporte (BOJA de 30 de enero). 
de apremio en las reclamaciones económico-administrativas ${ }^{15}$ o la tramitación, incluso, de procedimientos sancionadores ${ }^{16}$, etc. Q uede claro que en estos actos el órgano administrativo que aparece como resolutor ante los particulares es el encomendero, sin que haya ningún otro acto del encomendante que lo recoja o integre.

\section{NATURALEZA JURÍDICA}

\section{Su naturaleza convencional}

La encomienda de gestión es un negocio jurídico bilateral que consta de dos fases bien definidas: en la primera, puede decirse que existiría una primera etapa de actividad informal en la que un órgano o Entidad toma la decisión unilateral de encomendar una actividad por razones de eficacia, y decide qué otro órgano o Entidad de la misma o distinta Administración podría cumplir mejor dicha tarea. Tras lo cual comenzarían las negociaciones entre ambas partes encaminadas a verificar o no la disponibilidad de la parte encomendada a aceptar el encargo ( si la forma de sustanciar la encomienda fuera el convenio, bien por la no existencia de previsión al respecto, bien por su previsión expresa) y en qué términos, o negociaciones dirigidas exclusivamente a concretar el objeto de la encomienda ( si se tratara de una encomienda forzosa entre órganos jerarquizados de la misma Administración y así se contemplase en la normativa interna sobre formalización de encomiendas de gestión).

En una segunda fase se perfeccionaría el negocio jurídico en sí, a través de convenio (en los casos en que así sea) o del dictado de la Resolución por la que el órgano encomendante ordena a otro inferior la realización de la actividad encomendada (en los casos en que así se prevea).

Tal y como expresa el art. 3.1,c) del Texto refundido de la Ley de Contratos de las Administraciones Públicas (TRLCCAAPP), los convenios de colaboración interadministrativos se excluyen del ámbito objetivo de la Ley. Esto llevaría, en mi opinión, a conceptuar la encomienda como un negocio jurídi-

\footnotetext{
15 Resolución de 26 de diciembre de 2.001, de la Secretaría General Técnica de la Consejería de Sanidad y Consumo de Canarias (BOCAN de 29 de diciembre).

${ }^{16}$ Orden de 30 de julio de 1.999 de la Consejería de Salud de la Junta de Andalucía (BOJA de 19 de agosto).
} 
co bilateral de naturaleza convencional no contractual. Y ello por las siguientes razones:

- Se trata de un pacto cuya causa no es onerosa o sinalagmática al estilo de los contratos, sino gratuita: las dos partes son Administraciones, lo que impide el ánimo de lucro que, de existir, haría que el negocio fuera anulable por incurrir en desviación de poder. Ninguna de las dos partes celebra el convenio con la intención de sacar provecho propio; al contrario, la intención de las partes es la misma: contribuir a la satisfacción de los intereses generales en la medida en que una prestación o actividad determinada es realizada por la parte que mejor puede desempeñarla, colaborando el encomendero de una manera gratuita (recordemos que la encomienda suele realizarse sin que el encomendante transfiera medio personal, económico o técnico alguno al encomendero). Encomendante y encomendado están de acuerdo en cuál de las dos partes presta mejor el servicio y ponen todo de su parte para lograr ese objetivo común. Es decir, el encomendado su capacidad, su personal y su tiempo, y el encomendante sus directrices y resoluciones directivas para dar sustento formal a la actividad material a realizar, pudiendo llegar, si lo desea, a comprometerse a transferir medios al encomendado ${ }^{17}$, compromiso cuyo incumplimiento generaría responsabilidad de tipo contractual a favor del encomendero, conforme al art. $1.124 \mathrm{CC}^{18}$. Si los medios que el encomendante se comprometió a transferir eran monetarios, su incumplimiento devengaría el nacimiento del interés legal del dinero a favor del encomendero, desde el momento en que debieron entregarse dichos medios ${ }^{19}$.

- Es patente que, siendo ambas partes Administración, no pueden perseguir ningún tipo de lucro en el negocio. Los posibles beneficios son siempre externos, siempre de la ciudadanía que se beneficia indirectamente, de la prestación material que ésta lleva a cabo con fines instrumentales

17 Resulta paradójico que, junto con la actividad encomendada, el encomendante transfiera también al encomendero los medios personales, materiales, económicos o técnicos necesarios para desarrollar la actividad puesto que la encomienda se produce, supuestamente, porque el encomendante no tiene los medios adecuados para desarrollarla. Aparte de que en los casos en que la encomienda se realiza a favor de las EE.LL. esto obedece a una finalidad descentralizadora de la competencia y está legitimada en sí misma, en los casos en que esta transferencia de medios se realiza en el ámbito inter o intraestatal o autonómico, las encomiendas se realizan para evitar otro tipo de ineficacias, no mediales sino temporales o de calidad de la prestación.

18 STSJ Comunidad Valenciana de 16 de mayo de 2.001.

19 Vid. STSJ de Cantabria de 11 de junio de 1.999 o STSJ de Cataluña de 20 de julio de 2.000. 
para el encomendante 0 a la que va destinada la prestación directa del encomendero.

- El hecho de que la causa del negocio no sea onerosa no obsta a que cada parte busque en la encomienda algún otro interés que no sea el estrictamente externo. Así, la parte encomendada puede ambicionar la encomienda con vistas a defender sus competencias en la conformación del interés general al que tiende (así, el Ayuntamiento o Diputación Provincial al que, por cercanía con el ciudadano, una Comunidad Autónoma le encargara la gestión de competencias propias). Y la parte encomendante puede pretender con la encomienda liberarse de obligaciones materiales que, aparte de tediosas y poco importantes, pueden hacerle perder un tiempo precioso que necesitan para metas más importantes. Estas "ganancias colaterales" o internas no son suficientes para desvirtuar la definición convencional y gratuita que hemos hecho de la encomienda, ya que no se insertan jurídicamente en la causa del mismo, sino como consecuencias sobrevenidas, si bien deseadas con carácter previo al negocio, en el plano puramente volitivo.

Teniendo en cuenta la causa gratuita del negocio, no cabría igualar, como hace alguna doctrina, la encomienda de gestión con los contratos administrativos de obras, de servicios, de gestión de servicios públicos o de consultoría y asistencia, haciendo ver que el encomendante es el contratante y el encomendero el contratista ${ }^{20}$. Tal vez la confusión radique en que en dichos contratos se llevan a cabo actividades materiales, de servicios o técnicas y que sí es cierto también que desde un punto de vista subjetivo podrían asemejarse bastante ambos negocios puesto que tanto en la encomienda como en el contrato de servicios el encomendante o el contratante tiene atribuida, con carácter previo, la competencia u obligación jurídica de prestar la actividad o servicio, de manera que, de no encontrar a un órgano administrativo o Entidad más capacitado que él para llevarla a cabo, o a un contratista en el caso del contrato, estaría obligado a desempeñarla con sus medios propios (en el contrato), o a hacerse con ellos si no los tuviera (para el caso de la encomienda) ; en el caso del contrato esto nos llevaría a la gestión directa de un servicio o servicio público, o a la realización de los contratos de obras y de servicios mediante medios propios de la Administración, como recoge, v. gr. los arts. 152.1,c) ó 154.2 TRLCCAAPP).

20 De esta opinión es GONZÁLEZ NAVARRO, en GONZÁLEZ PÉREZ, J. y GONZÁLEZ NAVARRO, F., Comentarios a la Ley de Régimen Jurídico de las Administraciones Públicas y del Procedimiento Administrativo Común (Ley 30/1.992, de 26 de noviembre), Tomo I, editorial Civitas, Segunda Edición, Madrid, 1.999, págs. 744, 745 y 748. 
Sí puede ocurrir que una encomienda celebrada entre dos órganos administrativos pueda tener objeto de contrato administrativo, pues el encomendante encarga al encomendero, verbigracia, la gestión de estadísticas, o la prestación del servicio ambulatorio de renovación del documento nacional de identidad. En estos casos, puesto que la causa del negocio sigue siendo gratuita, no cabría hablar tampoco de contratos ni aplicar el TRLCCAAPP con la excusa de que ese convenio no es de los excluidos de su art. 3. Por el contrario, el ámbito objetivo de la encomienda sí puede solaparse con los contratos administrativos, y ello porque así se lo permite a las Administraciones la cláusula de la libertad de pactos (art. 4 TRLCCAAP, art. 57 LRBRL, art. 111 TR de las Disposiciones Vigentes en materia de Régimen Local). Podemos decir, por tanto, que los límites que el art. 15.1 LRJAPyPAC impone a la encomienda de gestión son puramente negativos (que no se encomienden actividades formalizadas como la tramitación de procedimientos, su resolución o el dictado de actos administrativos), pero, presupuesto esto, el juego de la cláusula de libertad de pactos permite al encomendero encargar cualquier tipo de actividad material, técnica o de servicios, siempre que no sea contraria al interés público, al Ordenamiento jurídico ni al principio de buena administración. Por cierto, que este último principio citado sí ha de tener un papel fundamental, ya que impediría la encomienda de actividades que el encomendante pueda realizar con mayor eficacia o eficiencia que el encomendero.

\section{Distinción respecto de la delegación de competencias}

Es precisamente la mayor amplitud, importancia y sustantividad de las competencias que pueden ser susceptibles de delegación, en relación con la encomienda, lo que diferencia ambas figuras, y lo que explica que el art. 13.5 LRJAPyPAC prohíba delegar lo delegado, mientras que el art. 15 sí permite encomendar o delegar lo encomendado. Así lo han proclamado varias sentencias de algunos Tribunales Superiores de Justicia ${ }^{21}$.

No obstante ello, nos parece que estas resoluciones judiciales se equivocan al querer diferenciar la delegación y la encomienda por su ámbito subjetivo, ya que consideran que mientras que la delegación se da entre órganos jerarquizados, la encomienda se produce entre órganos no jerarquizados de la

${ }^{21}$ Así lo entiende la jurisprudencia: Sentencias del TSJ Murcia de 30 de octubre de 1.999, de 31 de diciembre de 2.001 y de 20 de mazo de 2.002, y del TSJ de Castilla y León de 1 de marzo y de 20 y 27 de septiembre de 2.001 y de 20 de septiembre, de 18 y de 21 de octubre y de 15 de noviembre de 2.002 . 
misma o distinta Administración. Como sabemos, el art. 13 permite la delegación entre órganos no jerarquizados de la misma Administración, y el art. 15 contempla igualmente la encomienda de gestión entre órganos jerarquizados $^{22}$. Esta intercambiabilidad subjetiva determina que ambas instituciones tengan que diferenciarse desde el punto de vista de su objeto, como hemosindicado, más amplio en el caso de la delegación (en la que puede concitarse la realización de actividades sustanciales o formalizadas) que en el de la encomienda (donde sólo se tolera la prestación de actividades materiales). A veces los términos, inevitablemente, se confunden ${ }^{23}$.

Pero no sólo por su objeto. También en la forma de perfeccionamiento de ambas figuras se encuentran diferencias, ya que incluso la encomienda entre órganos jerarquizados puede plasmarse en cualquier tipo de acuerdo de voluntades, generalmente en un convenio ${ }^{24}$, mientras que la delegación intraadmnistrativa no es un negocio jurídico en sentido estricto dada la circunstancia de que no concurren dos voluntades sino exclusivamente la del órgano delegante, que, de manera unilateral, decide encargar el ejercicio de una competencia a un órgano inferior. Por razones de fondo y por aplicación analógica del art. 15 LRJAPyPAC, cabría pensar que en los casos en que la delegación se produce entre órganos no jerarquizados de la misma o distintas Administraciones debería utilizarse el convenio siempre que la competencia ejercida sea material, técnica o prestacional, y también como forma recomendable para el respeto de las competencias del órgano delegado cuando las competencias de que se trate sean sustantivas (arts. 27 y 37 LRBRL).

22 Las SSTSJ de Extremadura de 27 y 28 de mayo de 1.999 y de 7 de junio de 2.002 reconocen implícitamente la posibilidad de realizar encomiendas de gestión entre órganos jerarquizados, ya que considera que la liquidación de impuestos realizada por los Registradores de la propiedad por encomienda de la Comunidad Autónoma se realiza en un régimen de dependencia funcional relativa respecto de ésta (si bien no orgánica) constituyendo una especie de contrato administrativo de prestación de servicio.

${ }^{23}$ Así ocurrió con la encomienda de gestión celebrada entre la Secretaría General de Medio Ambiente y el O rganismo Autónomo Parques Nacionales - Resolución de la Secretaría General de Medio Ambiente de 15 de julio de 2.002 (B.O.E. de 30 de agosto) -, que es denominada indistintamente como "encomienda de gestión" y como "delegación técnica", quizás en la equivocada creencia de que lo encomendado excedía de lo puramente material permitido por una encomienda.

${ }^{24} \mathrm{Ni}$ que decir tiene que los convenios de encomienda entre órganos jerarquizados no son acuerdos plenamente libres, pues la jerarquía existente entre las partes y la amenaza latente de que en caso de fallo de las negociaciones el órgano superior puede imponer su encomienda de manera forzosa limitan la autonomía de la voluntad del órgano inferior. 
SOSA WAGNER y DE MIGUEL GARCÍ ${ }^{25}$ consideraron que eran cuatro las diferencias principales existentes entre delegación y encomienda, cifrándolas en que:

1‥ La delegación es voluntaria y la encomienda forzosa;

2o. La delegación es "convenida" y ésta es una relación impuesta, de dirección y control;

3o. El ámbito objetivo de la primera es el de las competencias compartidas o concurrentes, mientras que en la segunda las competencias son plenas, en especial las de carácter material;

4ㅇ․ El ente delegado actúa bajo su propia responsabilidad, ya que hay una transferencia real del ejercicio de las competencias, mientras que en la asignación o encomienda la transferencia es sólo aparente, siendo la responsabilidad final de la prestación del encomendante, y sólo se produce una simple utilización de los medios del encomendero.

Resulta meritorio el temprano esfuerzo clarificador de esta institución por estos autores, pero parece obvio que las notas de la encomienda tradicional a nivel local antes de la entrada en vigor de la Ley 30/ 1.992 eran totalmente opuestas a las que luego hemos conocido, ya que, efectivamente, la encomienda también es voluntaria y "convenida", y, aunque generalmente es cierto que supone el encargo de competencias propias del encomendante, también ocurre que se encomiendan competencias compartidas, 0 , al menos, competencias en las que el ente encomendero también tiene intereses, como ocurre cuando el Estado o una Comunidad Autónoma encomiendan el ejercicio de una competencia a una entidad local porque entienden que comparten con ella intereses. Por último, en la encomienda moderna la responsabilidad de la prestación es plena del encomendero, contra quien podrán recurrir los particulares y el propio encomendante en última instancia, en las circunstancias que señalamos en esta investigación.

El ámbito natural de la delegación de competencias del art. 13 LRJAPyPAC es el de las relaciones entre órganos jerarquizados, y es por eso por lo que el apdo. $1^{0}$ de ese precepto sitúa las delegaciones en el ámbito estatal 0 auto-

${ }^{25}$ Vid. SOSA WAGNER, F. y DE MIGUEL GARCÍA, P., Las competencias de las Corporaciones L 0cales, Instituto de Estudios de Administración Local, 1.985, pág. 94. 
nómico dentro de cada Administración (art. 13.1 LRJAPyPAC); no obstante ello, la especialidad del régimen local sí permite la delegación interadministrativa de competencias desde aquellas Administraciones a las EE.LL., como recogen los arts. 27 y 37 LRBRL. Como nos recuerda también GALLEGO ANABITARTE, los actos dictados por delegación son, a los efectos de su impugnación, actos dictados por el delegante 26 .

\section{RÉGIMEN JURÍDICO}

\section{El apdo. 29 del art. 15}

La obligación recogida en el apdo. $2^{\circ}$ del art. 15 de la LRJAPyPAC debe interpretarse en un sentido literal. Es decir, el órgano o entidad encomendante tiene la obligación de dictar las resoluciones o actos administrativos finalizadores de los procedimientos que previamente han tramitado o cuyas propuestas de resolución han sido hechas por el órgano o entidad encomendado.

Pero también cabría hacer una interpretación complementaria de lo que se puede entender por "actos que den soporte a la actividad material objeto de la encomienda". Efectivamente, como las demás figuras del Capítulo II del Título I de la Ley 30/ 1.992, la encomienda de gestión no supone la transferencia de la titularidad de la competencia sino sólo la de su ejercicio, de manera que cuando el encomendante considere incumplida la encomienda en los términos establecidos en el instrumento de formalización de la misma, y siempre que en él así se diga, podrá revocarla y rescatar el ejercicio de la competencia cedido. Al retener la titularidad de la misma, el apdo. 20 del art. 15 LRJAPyPAC obliga al encomendante a dictar las instrucciones, circulares 0 actos administrativos encargados de encauzar, corregir u ordenar la actividad

\footnotetext{
26 Vid. GALLEGO ANABITARTE, A., Transferencia y descentralización; delegación y desconcentración; mandato y gestión o en comienda. Teoría jurídica y derecho positivo, en R.A.P. no. 122 (mayo-agosto 1.990), pág. 39 y ss. Y ello es así a diferencia de lo que ocurre en la encomienda de gestión del art. 15 LRJAPyPAC, en la que la responsabilidad de la prestación es del encomendero y un particular podría recurrir directamente frente a él si su actuación le causó daños y aún no existiera un acto administrativo del encomendante que le diera soporte. A diferencia también de la encomienda, la delegación es revocable en cualquier momento, aunque parece que, para los casos de delegaciones de los arts. 27 y 37 LRBRL, la importancia de la autonomía local impediría las revocaciones por motivo de oportunidad. Este autor no desarrolla una teoría de la encomienda de gestión en sentido estricto, sino que hace equivaler esta figura con lo que él denomina "gestión", en alusión a la gestión ordinaria de los servicios autonómicos por las Diputaciones Provinciales.
} 
material objeto de la encomienda. Ésta sí que es una obligación irrenunciable del ente u órgano encomendante, que nunca podrá delegar o ceder al encomendero salvo dentro de los límites de las instrucciones o acuerdos previamente establecidos ${ }^{27}$, aunque así lo dijera expresamente ${ }^{28}$.

\section{Sobre el control de la actividad encomendada}

Aunque el art. 15 LRJAPyPAC no dice nada acerca de los mecanismos de control a posteriori e impugnación de la actividad encomendada, debemos dedicar al gunas reflexiones a este respecto, ya que no se trata en absoluto de una cuestión sin importancia. La Ley parte de la creencia que la actividad encomendada no va ser impugnada por los administrados, bien porque la misma suele suponer un facere a favor del órgano encomendante sin efectos externos, bien porque aun cuando pueda tener efectos ad extra frente a los ciudadanos, su carácter material, técnico o de servicios la hace poco idónea para ser formalizada en actos o resoluciones susceptibles de impugnación. A pesar de ello, hemos visto que son muchos los casos en que el objeto de la actividad encomendada es de tal naturaleza que su realización puede suponer actos de gravamen o provocar daños en los administrados. En este caso, ¿ante qué órgano y cómo podrá el particular impugnar esa actividad?

Debemos partir de la idea general de que los particulares acabarán recurriendo en vía administrativa o contenciosa contra un acto administrativo, y éste suele venir constituido por la resolución del encomendante que da soporte a la actividad material del encomendado. Sin embargo, no es menos cierto que el responsable de la correcta actuación de la encomienda es el ór-

\footnotetext{
27 Pueden darse casos en que se ceda la potestad de dictar instrucciones o incluso de aprobar la normativa de gestión de la actividad encomendada y que ello se realice dentro de los cánones preestablecidos, por ejemplo, en una Conferencia Sectorial recogida en un convenio, propio del art. 8.2 LRJAPyPAC.

${ }^{28}$ Aunque pocas, existen algunas encomiendas en las que la potestad de dictar las instrucciones de la encomienda se haya cedido también al encomendero, siendo, por lo dicho, cláusulas nulas de radice por incompetencia material. Así sucedió en el convenio de encomienda celebrado entre el F.E.G.A. y la Dirección General de Agricultura para la tramitación de las ayudas a los planes de mejora de los frutos secos y a las agrupaciones de productores prerreconocidas, recogido en la Resolución de la Presidencia del F.E.G.A. de 13 de diciembre de 2.001 (B.O.E. de 4 de enero de 2.002), en cuya cláusula 9a el encomendero, en cumplimiento de las funciones encomendadas, se obliga a emitir las instrucciones por escrito que sean precisas para el empleo de las listas de control en la preparación de las propuestas de pago, de seguridad y controles informáticos adecuados, las comprobaciones administrativas y los exámenes físicos que ha de realizar.
} 
gano encomendero, a quien compete el ejercicio de las competencias encargadas. Evidentemente, cuando el daño causado a un tercero provenga de un "no hacer" del órgano encomendero en relación con una obligación de actuar recogida en el instrumento de formalización de la encomienda, la vía normal de control es la del art. 29.1 de la Ley Jurisdiccional. Cuando el daño hubiera sido infligido por una actuación material (sobre todo en el caso de prestación de servicios a terceros), habrá que estar a la circunstancia de que dicha actuación estuviera o no prevista en el instrumento de la encomienda: si lo estaba, es decir, si la actuación contaba con cobertura jurídica, parece lógico permitir que el administrado pueda optar entre demandar por el interdicto contencioso al encomendero (art. 30 Ley Jurisdiccional) o impugnar el mismo convenio de encomienda (solución bastante difícil en la práctica, pues pocas veces, de la celebración de un convenio, un particular podrá sentirse afectado en sus derechos; otra cosa es que el afectado fuera otro órgano administrativo, caso más normal que se daría cuando las competencias encomendadas pertenecieran en realidad a dicho órgano y no al encomendante, constituyendo una especie de conflicto intra o interadministrativo de competencias), para el caso en que el daño provenga de una actuación del encomendero escrupulosamente ajustada a lo prescrito en él. Si el daño fue motivado por una actuación material que, pese a estar establecida en el convenio, se extralimitó o ejecutó negligentemente, entonces la única forma normal de impugnación será la de impugnar la vía de hecho.

Dada la naturaleza administrativa de los convenios de encomienda (inherente a los convenios de colaboración del art. $3.1 \mathrm{c}$ ) yd) del TRLCCAAPP), la jurisdicción competente para dilucidar los litigios que puedan surgir entre las partes y entre los particulares y cualquiera de ellas será la contencioso-administrativa, y, en particular, los órganos judiciales encargados de resolverlos serán las Salas de lo contencioso-administrativo de los Tribunales Superiores de Justicia o de la Audiencia Nacional (arts. 10.1,g) y 11.1,c) de la Ley Jurisdiccional).

De todas formas, ateniéndonos a la praxis administrativa existente, parece que lo normal es que las impugnaciones de los particulares vayan dirigidas frente a actos administrativos en que se haya plasmado la actividad encomendada. En estos casos el ciudadano afectado seguirá la vía administrativa y contenciosa normal ya sea en relación con el órgano encomendante, que es quien suele dictar la resolución final que finaliza el procedimiento concreto en que se haya plasmado la encomienda, y cuya propuesta realizó, como acto de trámite, el encomendero, o en relación con el órgano encomendero que dictó el acto de trámite o realizó la propuesta de resolución, si ese acto era susceptible 
de recurso autónomo conforme a los criterios establecidos en el art. 107 LRJAPyPAC ${ }^{29}$.

Los administrados preferirán impugnar la actividad del órgano que "da la cara ante ellos", es decir, del encomendante, y no necesariamente del que la Ileva a cabo, es decir, del encomendero. Si se solicitara y concediere responsabilidad patrimonial, el encomendante podría repetir contra el encomendado en el porcentaje que se estableciera en el convenio o en su integridad, si en él nada se dijo ${ }^{30}$.

\footnotetext{
29 Puede ocurrir que el acto administrativo consistente en la propuesta de resolución realizada por el encomendero fuera susceptible de recurso administrativo autónomo, por poner fin al procedimiento para un interesado determinado. Así ocurría, a nuestro juicio, en el caso resuelto por el Auto de 27 de septiembre de 2.001 del Tribunal Supremo, en el que un magistrado interpuso recurso contencioso frente a una Resolución del Presidente del C.G.P.J. por la que éste excluyó al recurrente de la relación de candidatos a vocal del Consejo, a nombrar posteriormente por las Mesas de las Cortes Generales. La Disp. Transit. Única de la LOPJ encomendaba al Presidente del Consejo la elaboración de la lista de los 36 candidatos a vocales del mismo (ex art. 112 LOPJ). EI Auto califica este negocio como encomienda de gestión del art. 15 de la LRJAPyPAC, y la resolución impugnada del Presidente del C.G.P.J. como un acto preparatorio de la decisión final del procedimiento parlamentario de designación de vocales de procedencia judicial del C.G.P.J. Comoquiera que la Resolución final de las Cortes nombrando a los vocales no podía ser objeto de control por la jurisdicción contenciosa, conforme al art. 1.3,a) de la Ley Jurisdiccional, el Auto inadmitió el recurso porque entendió que la Resolución del Presidente del CGPJ se igualaba a la Resolución final del procedimiento por las Cortes, y, por tanto, no susceptible de control judicial. La solución es muy discutible, pues el propio Tribunal parece aludir a razones de justicia material, reconociendo expresamente que, de admitir el recurso, se prolongaría el nombramiento del C.G.P.J., con las consecuencias materiales que ello acarreara. En su estupendo voto particular, el Magistrado Trillo Torres considera que la encomienda, en este caso, iba más allá de lo que puede denominarse como actuaciones materiales del art. 15 LRJAPyPAC y que configuraba una actuación formal o acto administrativo de trámite plenamente fiscalizable ante la jurisdicción contenciosa, ya que la Resolución del Presidente del C.G.P.J. determinaba irremediablemente el ámbito subjetivo de los vocales de procedencia judicial que integrarían el Consejo, sin que las Cortes Generales tuvieran potestad de enmienda alguna sobre el mismo.

Casi siempre el acto administrativo de trámite suscrito por el encomendero limita el ámbito objetivo o subjetivo de actuación del encomendante, quien podrá dictar su resolución pero, casi siempre, repetimos, dentro de los límites prefijados por el encomendero. Así ocurre en la selección de candidatos con vistas a ocupar puestos laborales en una Administración Pública, v. gr. Por el contrario, no sería normal que el encomendante tuviera potestad de apartarse de lo prefijado por el encomendero, pues en seguir su dictado está la eficacia que motivó la encomienda, pero si pudiera hacerlo con puro carácter discrecional (no por error del encomendero) entonces parece que no cabría la impugnación autónoma del acto del encomendado pues no nos encontraríamos antes los supuestos del art. 107 LRJAPyPAC.
}

30 La responsabilidad sería del encomendero si el nexo causal acaba en él, como responsable de la actividad ejercida. Cfr. GO NZÁLEZ PÉREZ, J. y GO NZÁLEZ NAVARRO, F., Comentarios a la Ley... opus cit., pág.749. 
Aparte los efectos externos de la encomienda, la mayoría de las veces sus instrumentos de formalización suelen contener mecanismos de control de la actividad encomendada por parte del órgano o entidad encomendante, que vienen a conformar cláusulas de garantía para asegurarse la correcta realización y los estándares de calidad imprescindibles de lo que se va a actuar. Suelen consistir en la obligación del encomendero de emitir informes de resultados al encomendante, con inclusión de los criterios de realización, de los procedimientos empleados o del alcance cualitativo y cuantitativo de la actividad realizada. O tras veces, para casos en que la encomienda consista en la gestión de fondos públicos, se permite al encomendante la realización de controles 0 auditorías que aseguren de alguna manera que los fondos han sido correctamente empleados ${ }^{31}$.

Cuando la encomienda fuera incumplida o cumplida de manera no satisfactoria a juicio del encomendante, podrá éste hacer recaer sobre él las consecuencias previstas en el convenio o las que legalmente le fueran imputables $^{32}$, hasta llegar, incluso, si las partes en la encomienda eran dos Administraciones Públicas, al requerimiento previo al recurso contencioso y a la sustanciación de éste mismo.

\section{El contenido de los convenios de encomienda}

Los convenios de encomienda celebrados entre órganos o entidades administrativos deben tener los elementos esenciales que recoge el art. 6 de la LRJAPyPAC, y que consisten en la determinación de: los órganos que celebran el convenio y la capacidad jurídica con la que actúa cada una de las partes; la competencia que ejerce cada Administración; su financiación; las actuaciones que se acuerde desarrollar para su cumplimiento; la necesidad o no de esta-

${ }^{31}$ Así ocurre, por ejemplo, en los convenios de encomienda suscritos por el F.E.G.A. (Fondo Español de Garantía Agraria) como encomendante con otros organismos homólogos autonómi$\cos$ (F.A.G.A. en Andalucía, v. gr.) o con otros órganos administrativos. Véase por todos el que se inserta en la Resolución de 20 de julio de 1.999 de la Presidencia del F.E.G.A. (B.O.E. de 31 de julio).

32 La STS de 25 de noviembre de 1.998 reconoció la responsabilidad de un recaudador de tributos y agente ejecutivo del Ayuntamiento de Segovia que realizaba sus funciones en concepto de encomienda de gestión por defectos en su cuenta de recaudación del año 1.989, quedando el recaudador a responder por los valores perjudicados en primer, segundo y tercer grado. Se trata de consecuencias económicas derivadas de las normas locales, autonómicas y estatales de recaudación, sobre todo el Decreto de 10 de octubre de 1.958, que regula el procedimiento de perjuicio de valores, y aplicable a las $\mathrm{H}$ aciendas Locales. 
blecer una organización para su gestión; el plazo de vigencia, lo que no impedirá su prórroga si así lo acuerdan las partes firmantes del convenio33; la extinción por causa distinta a la prevista en el apartado anterior, así como la forma de terminar las actuaciones en curso para el supuesto de extinción. De todas formas, como señala HERNANDO OREJANA, la locución adverbial condicional "cuando así proceda" del apdo. 20 de dicho art. 6 significa que no existe obligación de que todos los convenios tengan cláusulas atinentes a todos los extremos especificados, sino sólo de aquéllas que sean necesarias a juicio de las partes. Esto nos reafirma de nuevo en el relativismo jurídico al que parece estar abocada la encomienda de gestión, pues, según esto, los convenios en que se plasmen sólo tendrán que incluir las cláusulas relativas a la sustancia recognoscible de la institución tal y como viene regulada en el art. 15 LRJAPYPAC.

Eso sí, si la encomienda fuere suscrita entre una Administración y una persona física o jurídica sujeta al Derecho Privado los elementos imprescindibles serían los regulados en el art. 88 de la misma.

Aparte ello, teniendo en cuenta la especialidad de la materia y que la encomienda de gestión - como las demás formas de alteración del ejercicio de las competencias administrativas del Capítulo I del Título II de la LRJAPyPAC - es una forma extraordinaria de actuación administrativa desde un punto de vista competencial, la concreción precisa de las materias sobre las que se produce es el requisito formal más importante de todo convenio de encomienda. Es razonable pensar que cuando la encomienda se produzca entre órganos o entidades de Administraciones diferentes mayor celo pondrán las partes en determinar el alcance de las materias afectadas. Por el contrario, dentro de la misma Administración las funciones encomendadas pueden ser deliberadamente más ambiguas, bien porque no existan luchas internas por el ejercicio de competencias que son, a fin de cuentas, propias, bien porque el encomen-

33 La determinación del plazo de vigencia es una de las cláusulas imprescindibles también en los convenios de encomienda ya que así lo exige el carácter irrenunciable de las competencias administrativas. Por eso, serían nulas de radice las encomiendas temporalmente indefinidas, como la celebrada entre los Departamentos de Presidencia e Interior de la Comunidad Foral de Navarra y el Ministerio del Interior para la realización de las actividades técnicas relacionadas con la competencia en materia de juegos propia de la Comunidad, en convenio suscrito entre ambas y plasmado en la Resolución de la Secretaría General Técnica del Ministerio del Interior de 14 de julio de 1.998, en cuya cláusula 5a se dice que "El presente convenio tendrá carácter indefinido, pudiendo ser denunciado por cualquiera de las partes firmantes, con una antelación mínima de tres meses". 
dante busca su mayor descargo posible. En cualquiera de los dos casos, la exigencia de determinación de la actividad o actividades afectadas por la encomienda es común, y su vulneración, más allá del evidente vicio de anulabilidad formal propia del art. 63.1 LRJAPyPAC - cuando la actividad no está bien concretada, o lo está de manera amplia o genérica - puede llegar a constituir un vicio de nulidad por suponer la adquisición de facultades, de manera contraria al Ordenamiento jurídico y careciendo de lo requisitos esenciales para ello, si la actividad ejercitada no hubiera estado determinada en absoluto, ni en lo general ni en lo particular (art. 62.1,e) LRJAPyPAC) ${ }^{34}$.

Y, como en todo negocio jurídico bilateral los propios convenios son los que conforman la "lex partium", esto es, "la ley de las partes", lo mismo ocurre en la encomienda de gestión, sin contenido mínimo legalmente obligado - como hemos dicho arriba -, de manera que pueden integrarse en ellos cláusulas accesorias o principales de todo tipo, tomadas por cercanía material de las que integran los contratos administrativos:

- $\quad$ Cláusulas de relleno de lagunas: se prevé a veces que aquellas circunstancias nuevas e imprevistas que acaezcan en su vigencia se rellenen con los principios de las normas reguladoras de los contratos de las Administraciones Públicas ( art. 3.2 TRLCCAAPP) o con aqueIlas otras que expresamente se prevean en el convenio ${ }^{35}$;

${ }^{34}$ Según este criterio, muchas son las encomiendas de gestión que incurren en vicio de anulabilidad, por ser excesivamente amplias o genéricas o estar realizadas pro futuro sin ninguna limitación objetiva. Cabe citar a este respecto la mayoría de las Resoluciones de la Secretaría de Estado de Infraestructuras delegando funciones técnicas en el Ente Gestor de Infraestructuras: como ejemplo, las Resoluciones de 8 y 27 de noviembre de 2.001, de 8 de mayo, 27 de junio o 13 de septiembre de 2.002 o de 12 de febrero de 2.003, de dicha Secretaría de Estado, en las que el órgano encomendante encarga a la Entidad Pública Empresarial "Gestor de Infraestructuras Ferroviarias (G.I.F.)", junto a otras competencias bien determinadas "la realización de cuentas actividades de carácter material, técnico jurídico y de servicios que, correspondientes a las competencias propias de M inisterio de Fomento, sean precisas para la redacción de los estudios informativos del Proyecto de Corredor de Alta Velocidad del (...Cantábrico, p. ė..) sin que ello suponga cesión de la titularidad dela competencia ni de los elementos sustantivos de su ejercicio". O la encomienda plasmada en la Resolución de la Secretaría General de Producciones y Mercados Agrarios de 12 de abril de 1.996 (B.O.E. de 25 de abril), entre ésta y la Comunidad Autónoma de Andalucía (cláusula 3ạ i).

Este tipo de cláusulas residuales parece estar fuera de la mens legislatoris del art. 15.3, párr. 2oㅡ LRJAPYPAC.

35 Son pocos los casos de convenios de encomienda con cláusulas de integración de lagunas. Vid. Convenio de encomienda celebrado entre el F.E.G.A. y la Subsecretaría del departamento para tramitación de la ayudas derivadas de diversos programas, en Resolución de la Presidencia del F.E.G.A. de 10 de mayo de 2.002 (B.O.E. de 10 de mayo), que se remite a los Reglamentos Comunitarios en concordancia con el Reglamento (CE) 1.663/ 95 de la Comisión y a las disposiciones nacionales que sean de aplicación para regular todo lo no previsto en la encomienda. 
- Propio también de los convenios es la inclusión de una cláusula de resolución del convenio por mutuo acuerdo o por denuncia de alguna de las partes, que deberá ser comunicada a la contraparte con una antelación mínima determinada en el convenio;

- En lo que tienen de encargo, más o menos oneroso, en las encomiendas de gestión se suelen dar cláusulas de mantenimiento del equilibrio económico del negocio. Pero, teniendo en cuenta que en la mayoría de ellas no se transfieren al encomendero medios económicos o financieros, el equilibrio del negocio no se persigue a través de fórmulas económicas de estabilización de las prestaciones, del tipo "rebus sic stantibus", sino que, más bien, se permite la denuncia cuando se produjeran cambios legales, presupuestarios o de competencia que supongan un cambio en las condiciones que motivaron la encomienda (más al estilo del "factum principis") 36 ;

- Cláusulas de modificación conjunta de la encomienda37;

- $\quad$ Finalmente, pueden insertarse cláusulas sobre la recurribilidad de los actos o resoluciones del encomendante en los que se integre la actividad material objeto de la encomienda: si ponen o no fin a la vía administrativa, y, si causan estado, en qué plazos y ante qué instancias judiciales deben interponerse los recursos contencioso-administrativos pertinentes;

- Si bien no como cláusula formal del negocio convencional, el pórtico de todos los convenios lo conforma la motivación que lleva al encomendante a celebrar la encomienda, que toma asiento, por lo general, en la exposición de motivos de la resolución en la que se recoge el convenio de encomienda para su publicación. La ausencia de motivación ocasionaría la nulidad de la encomienda, ya que las competencias son irrenunciables, y la decisión de alterar su ejercicio que toda encomienda supone se hace en el marco de una potestad discrecional del encomendante, que, como tal, requiere motivación, como también la requiere la concreción, por el encomendante y el encomendando, de cuáles y en qué grado se encomiendan, lo que hemos denominado "discrecionalidad interorgánica 0 interadministrativa" (art. 54 LRJAPyPAC) ${ }^{38}$.

\footnotetext{
36 Vid., ad exemplum, la cláusula 2a del convenio de encomienda publicado por la Resolución de la Presidencia del F.E.G.A. de 20 de julio de 1.999 (B.O.E. de 31 de julio).

${ }^{37}$ Así, en la encomienda plasmada en la Resolución de la Secretaría General de Producciones y Mercados Agrarios de 12 de abril de 1.996 (B.O.E. de 25 de abril).

${ }^{38}$ Carecen, por ejemplo, de motivación, la encomienda de gestión celebrada entre el Ministro de Agricultura, Pesca y Alimentación y la Consejería de Agricultura y Pesca de la Junta de Anda-
} 


\section{Formalización de la encomienda}

El convenio es la forma ordinaria y subsidiaria de plasmación de la encomienda. El enfoque de la Ley en este aspecto de la institución parece querer forzar a un entendimiento entre las partes en juego, sin duda por influencia de los principios de solidaridad, colaboración, cooperación y subsidiariedad. El hecho de excluir de la necesidad convencional a las encomiendas entre órganos jerarquizados de la misma Administración ya la gestión ordinaria de los servicios autonómicos por las Diputaciones Provinciales y de los Cabildos o Consejos insulares (art. 37 LRBRL) revela el carácter de subordinación o coordinación que existe en dichas relaciones, incompatible muchas veces con el consentimiento del encomendero. En el primer caso, aunque puede darse razonablemente un convenio de encomienda entre órganos jerarquizados ${ }^{39}$, lo normal es que las negociaciones y pactos entre ellos se produzcan de manera informal, plasmándose en un simple acuerdo u orden interna, que, eso sí, exige publicidad de cara a los administrados, y, a veces, la aprobación de la encomienda por el órgano superior del encomendante. En el segundo caso, a diferencia de la importancia histórica de la autonomía local de los Municipios, la Ley parece despojar a las Diputaciones Provinciales de autonomía y criterio propios, teniendo que plegarse a la voluntad de las Administraciones superiores, conformando dicha encomienda una especie de "descentralización impropia" que más se asemeja a la desconcentración de funciones entre órganos de la misma Administración, actuando las Diputaciones en esos casos como auténticos instrumentos de la actividad autonómica.

Los convenios de encomienda, y, por tanto, la encomienda en sí misma, sólo producirá efectos desde el momento de la firma del convenio o instru-

\footnotetext{
lucía por la que se encarga al F.A.G.A. (Fondo Andaluz de Garantía Agraria) la gestión de determinadas actuaciones de intervención y gestión de mercados, recogida en la Resolución de la Secretaría General de Producciones y Mercados Agrarios de 12 de abril de 1.996 (B.O.E. de 25 de abril); y la celebrada entre la Comisión Permanente de la CICYT y el CESIC para la gestión del Programa Nacional de Física de Altas Energías, recogida en la Resolución de 23 de enero de 1.996 de la Secretaría de Estado de Universidades e Investigación (B.O.E. de 2 de febrero).

${ }^{39}$ Aunque entre ambos no haya una relación de jerarquía estricta, sí existe jerarquía orgánica entre el Ente Gestor de Infraestructuras Ferroviarias y la Secretaría de Estado de Infraestructuras y Transportes del Ministerio de Fomento, quienes han plasmados en convenios todas las encomiendas de gestión encargadas por ésta a aquél para la realización de los informes de supervisión de los proyectos constructivos de las líneas de alta velocidad. 0 , por ejemplo, el convenio de encomienda celebrado entre la Tesorería General de la Seguridad Social y el Instituto Nacional de la Seguridad Social (I.N.S.S.), publicado en la Resolución de 28 de abril de 1.999 (B.O.E. de 14 de mayo), de la Dirección General de la citada Tesorería.
} 
mento que la formalice, salvo que en ellos se disponga otra cosa, tal y como dispone el art. 8.2 LRJAPyPAC. Y sí, efectivamente se suele disponer otra cosa, ya que todos los convenios de encomienda se recogen en resoluciones del órgano encomendante (o de su superior, si él mismo no tiene capacidad de dictar actos administrativos) que se publican en los Diarios Oficiales correspondientes, y en las que expresamente se dispone que la entrada en vigor del convenio se produce el mismo día, al día siguiente a su publicación o cuando se establezca. Sólo ese puede ser el sentido de la exigencia de publicidad que impone el apdo. 30 del art. 15, para evitar que los efectos se produzcan desde la firma del mismo, que puede ser anterior a su publicación, lo que supondría una completa inseguridad jurídica y una ruptura del principio de confianza en la actuación Administrativa Pública de cara a los particulares afectables por la encomienda. Por la misma razón, también deben publicarse los acuerdos de terminación o prórroga de la encomienda.

Igualmente, como señala el art. 8.3 LRJAPyPAC, todos los convenios de encomienda, como convenios de colaboración que son, deberán comunicarse al Senado. Esta exigencia parece ir más allá del dudoso control que el Estado pueda ejercer sobre qué Administraciones y cómo ejercen las competencias, y llama más a la creación de una especie de registro de convenios en el Senado, como Cámara de representación territorial que es.

\section{SOBRE LA ENCOMIENDA DE GESTIÓN ENTRE ADMINISTRA- CIONES Y PERSONAS FÍSICAS O JURÍDICAS SUJETAS AL DE- RECHO PRIVADO}

Antes de nada debemos aclarar que, a mi juicio, lo que este apartado prohíbe no es la celebración de encomiendas de gestión entre Administraciones y particulares o empresas sino la aplicación del régimen jurídico del art. 15 LRJAPyPAC a los convenios de colaboración que se celebren entre ellos. Sabemos que estos convenios son los que se recogen en el art. 3.1,d) TRLCCAAPP, y que se encuentran excluidos del ámbito objetivo de la Ley de Contratos por tratarse de negocios jurídicos bilaterales de objeto no contractual, de manera que, cuando uno de esos convenios tenga por finalidad la construcción o concesión de una obra pública, la prestación de un servicio público, la realización de un suministro, el consejo técnico o la asistencia o la realización de servicios instrumentales, deberán ser considerados como contratos administrativos y sometidos al TRLCCAAPP y a la jurisdicción contencioso-administrativa. 
Entiendo que la encomienda de gestión a personas físicas o jurídicas sometidas al Derecho Privado existe, porque la causa del negocio es la misma que encontramos en la encomienda de gestión interadministrativa: colaborar para la consecución de un fin común y deseado por las dos partes, independientemente de que su régimen jurídico sea el de un contrato administrativo ( si la encomienda tiene, como hemos dicho, por ejemplo, objeto de contrato administrativo) o el de un convenio de colaboración de los del art 3.1,d) TRLCCAAPP (excluidos de esta Ley, precisamente, por no tener objeto contractual $\left.{ }^{40}\right)$. Aun reconociendo su diferente régimen jurídico, no nos parece necesario conceptuar la figura con otro nombre diferente cuando se celebra con personas o empresas. Los nombres de las cosas atienden a su naturaleza, si bien su régimen jurídico no tiene por qué seguir necesariamente a ésta, sino que puede responder a la necesidad de controlar las consecuencias negativas que de su mal uso pudieran derivarse ${ }^{41}$.

Es por ello por lo que las encomiendas de gestión del art. 15.5 LRJAPyPAC se deben someter al TRLCCAAPP cuando tengan objeto contractual, para evitar el fraude de ley que se seguiría de la inaplicación de los principios de publicidad y concurrencia, por ejemplo, si se celebrara una encomienda de gestión "a dedo" con una empresa privada sólo con la intención de ocultar un auténtico contrato administrativo. El hecho de que la empresa fuera un medio propio de la Administración, una sociedad anónima o limitada con una participación pública que no llegue hasta el 100\% (art. 154.2 TRLCCAAPP) no cambia en nada esa conclusión, ya que, al estar sometida al Derecho Privado, esa empresa debe siempre competir en pie de igualdad con el resto de empresas privadas españolas, y permitir la encomienda de una actividad de

\footnotetext{
40 Pertenecen a este tipo de negocios jurídicos la mayoría de los "acuerdos voluntarios", es decir, los convenios de colaboración para la protección del medio ambiente, celebrados por la Administración ambiental con, por ejemplo, propietarios de terrenos situados en el perímetro de un área protegida, con sectores industriales para reducir los niveles de emisión de determinadas sustancias, con empresas particulares a las que se ayuda a cumplir con la legislación ambiental existente, con propietarios de suelos contaminados, con las empresas que ponen envases o residuos de envases en el mercado, etc. Vid. SÁNCHEZ SÁEZ, A. J., L os convenios administrativos para la protección ambiental, I.A.A.P., Sevilla, 2.004.

41 Prueba de ello es que en muchos casos se denominan como "encomienda de gestión" los mandatos, autorizaciones o encargos realizados por una Administración a una empresa (así, por ejemplo, la encomienda de gestión celebrada entre el SEN PA y la empresa Frint España S.A., para retirar aceite en nombre de un grupo de sociedades adjudicatarias de un contrato administrativo) o a un particular (como ocurre en las relaciones laborales entre los Ayuntamientos y sus agentes recaudadores de tributos (Vid. STS de 25 de noviembre de 1.998).
} 
objeto contractual administrativo a una de ellas supondría la vulneración, en fraude de ley, todos los principios del Derecho Administrativo de Contratos, aparte de estar atentando contra la libre competencia del sector ${ }^{42}$.

Es por ello por lo que estimo el concepto de "persona jurídica sujeta al Derecho Privado" debe comprender también a las entidades instrumentales de Derecho Privado de las Administraciones, siempre que su capital no sea exclusivo de éstas. No obstante ello, existen casos en que una sociedad anónima municipal, de capital exclusivamente público, se ha equiparado a un particular a la hora de celebrar un convenio de encomienda de gestión con la Administración matriz o con cualquier otra, para evitar que con ello se adjudiquen auténticos contratos administrativos "puenteando" la Ley de Contratos ${ }^{43}$. Sin

\footnotetext{
42 Son innumerables los casos de encomiendas realizadas a personas jurídicas sujetas al Derecho Privado - a veces vinculadas a la Administración - con objeto contractual. Cabe citar el caso de la encomienda de gestión plasmada en la Resolución de 16 de septiembre de 2.002 (BONAV de 7 de octubre), del Depto. de Agricultura, Ganadería y Alimentación de Navarra, celebrada entre el Departamento de Agricultura, Ganadería y Alimentación de la Comunidad Foral de Navarra y la empresa "Gestión Ambiental de Viveros y Repoblaciones de Navarra, S.A." para la erradicación del Ilamado "fuego bacteriano", una plaga que atacaba a los árboles frutales de la Comunidad. La empresa tenía relación estatutaria con la Comunidad Foral ya que estaba adscrita al Departamento de Medio Ambiente, Ordenación del Territorio y Vivienda. Es un típico caso de huida el Derecho Administrativo de Contratos, ya que el encargo se concede "a dedo" y sin publicidad ni concurrencia mediante la encomienda y se evita tener que licitar un contrato administrativo típico de servicio como el que aquí se daba. Así sucedió también en el asunto que resolvía la STSJ Madrid de 21 de febrero de 2.001, en la que el Tribunal anuló una Resolución de la Mesa de Contratación de la Cruz Roja Española por la que excluía la oferta presentada por una empresa privada (Vencer España, S.A.) del concurso celebrado para el suministro de alimentos procedentes de las existencias de intervención comunitarias. La Cruz Roja española había celebrado con el F.E.G.A. una encomienda de gestión para licitar y recepcionar los productos suministrados (entre ellos, queso fundido) y repartirlos entre las personas más necesitadas. El Tribunal califica a la Cruz Roja como una persona jurídica (Fundación sujeta a la Protección del Estado) sujeta al Derecho Privado, lo que excluía la calificación del convenio celebrado con el F.E.G.A. como encomienda de gestión, ya que así lo prohibía - sic - el art. 15.5 LRJAPyPAC. Por tanto, el convenio celebrado, para suministro y distribución de alimentos, si bien para el Tribunal no puede ser denominado encomienda de gestión sí que se trata de un convenio del art. 3.1.d) TRLCCAAPP que, por tener objeto de contrato administrativo debe someterse al Derecho Administrativo y a los tribunales contenciosos, conforme al art. 1 de la Ley Jurisdiccional y al art. 9.4 LOPJ.
}

${ }^{43}$ Así lo entendió el TSJ de Castilla-La Mancha en su Sentencia de 30 de octubre de 2.000, considerando fraudulenta una encomienda de gestión celebrada entre el Ayuntamiento de Huete y el de Alcázar de San Juan para que la sociedad anónima municipal de aguas de éste prestara a aquél el servicio de abastecimiento de aguas. El convenio de encomienda fue declarado nulo al no tratarse de un convenio interadministrativo propiamente dicho (ya que el encomendado no era realmente un Ayuntamiento sino una persona jurídica sujeta al Derecho Privado) aplicándo- 
embargo, este tipo de encomiendas a sociedades anónimas municipales no sería tanto como "desmunicipalizar" los servicios públicos y la gestión indirecta del mismo, ya que no regiría aquí la exigencia de la previa selección del contratista. Ahora bien, si el capital público en la empresa privada no fuera del $100 \%$, no podría consentirse este tipo de convenio de encomienda sin aplicar el TRLCCAAPP, ni siquiera al amparo del auxilio interadministrativo (art. 57 LRBRL) pues nunca podría amparar un fraude de ley ${ }^{44}$.

Cuestión diferente es si existe una obligación del encomendante de someterse a los principios del Derecho Administrativo de Contratos a la hora de encomendar a otras entidades con personalidad jurídica pública la realización de actividades que tengan por objeto un contrato administrativo. Es decir, si existe un derecho del sector privado a concurrir y competir por cualquier encargo que tenga por objeto un contrato de obras, de concesión de obra pública, de suministro, de gestión de servicios públicos, de consultoría y asistencia o de servicio o si, por el contrario, puede la Administración no licitar dichos encargos porque prefiera adjudicárselos sin concurrencia ni publicidad a organismos públicos propios o de otra Administración. Decimos organismos públicos o con personalidad pública porque ya hemos dicho que si se tratara de sociedades estatales o de cualquier sociedad anónima o limitada con participación pública no podría realizarse a su favor una encomienda de objeto

se la Ley defraudada, la Ley de Contratos de las Administraciones Públicas. En dicho convenio el Ayuntamiento cedía a la empresa incluso la potestad administrativa de aprobar las tarifas del servicio.

Otras veces las sociedades anónimas municipales son consideradas entes instrumentales de la Administración, por lo que se admite la concreta encomienda de gestión hecha a su favor, como nos relata HERNANDO OREJANA, L. C., La Encomienda de Gestión, Colegio Universitario de Segovia, Segovia, 1.998, págs. 134 y 135, celebrada entre un Organismo Autónomo (el Instituto de la Vivienda de Madrid) y la Sociedad Anónima "Viviendas Sociales de Madrid, S.A." (posteriormente denominada SEGIPSA, Sociedad Estatal de Gestión Inmobiliaria de Patrimonio, Sociedad Anónima), para la construcción de una serie de viviendas y obras de urbanización en terrenos de aquél. Es evidente que esta encomienda escondía un auténtico contrato administrativo de obras.

${ }^{44}$ El Consejo de Estado consagró en su Dictamen 3.881/2.000, sin embargo, una encomienda de gestión realizada entre la Consejería de O bras Públicas, U rbanismo y Transportes de la Generalidad Valenciana y el Instituto Valenciano de la Vivienda, S.A., para la construcción de viviendas. Las opiniones del Consejo de Estado sobre la encomienda de gestión distan bastante de ser legalistas, ya que en su Dictamen 3.138/ 2.000 considera que la encomienda sólo puede tener lugar dentro de la misma Administración, y que no es voluntaria sino obligatoria, incluso cuando se da entre Administraciones diferentes. ¿Se quedó el Consejo de Estado anclado a la antigua encomienda como carga impuesta a las entidades locales? 
contractual, porque así lo prohíbe el art. 15.5, teniendo que someterse a los principios de publicidad y concurrencia del TRLCCAAP45.

Pues bien, a mi juicio, si la Administración puede prestar sus servicios públicos de manera directa también podrá hacerlo a través de una encomienda de gestión a un ente con personalidad pública, ya que ésta estaría actuando como si fuera la Administración matriz. Y, como muestra, dos botones: las dos encomiendas de gestión que el Departamento de Industria de la Comunidad Autónoma de Aragón celebró con el Instituto Tecnológico de Aragón (una entidad de derecho público, sin ánimo de lucro, con personalidad jurídica, patrimonio propio y plena capacidad para el cumplimiento de sus fines) para, por un lado, la gestión de servicios del programa DISEÑA, un proyecto público cuya intención era la modernización y asesoramiento a las empresas industriales aragonesas del sector textili6, y, por otro, la gestión de los servicios de las tecnologías genéticas y de diagnóstico molecular para las empresas dedicadas a la bioindustria ${ }^{47}$. Es evidente que se trata de encomiendas que tienen por objeto la prestación de sendos servicios públicos a unos determinados usuarios, que eran las empresas aragonesas de los sectores textil y bioindustrial.

Una excepción a la imposibilidad de encargar funciones públicas a personas jurídicas sujetas al Derecho Privado es la liquidación de impuestos de gestión autonómica a los Registradores de la Propiedad, porque, si bien no son funcionarios, su carácter híbrido les permite desarrollar este tipo de en-

\footnotetext{
45 Más lejos llega HUERGO LORA, A., La libertad de empresa y la colaboración preferente de las Administraciones con Empresas Públicas, en R.A.P. no. 154 (enero-abril 2.001), págs. 129-171, al considerar que la regla del contratista interpuesto no rige en nuestro Derecho Administrativo como obligación, ni siquiera para los contratos de obra, desprendiéndose del sistema económico recogido en nuestra Constitución la libertad de la Administración de licitar o no un encargo realizado a empresas públicas sometidas al Derecho Privado. Aun estando de acuerdo con sus conclusiones en lo que respecta a empresas públicas sujetas al Derecho Administrativo, consideramos necesario someter a los principios del Derecho Administrativo de Contratos las adjudicaciones realizadas a sociedades anónimas estatales o municipales siempre que su capital no sea exclusivamente público, ya que, de lo contrario, se estarían incumpliendo los principios de eficacia y eficiencia del actuar administrativo (art. 154.2 TRLCCAAPP)y de eficiencia y mejor servicio al ciudadano (art. 3 LRJAPyPAC).

46 Vid. Orden de 11 de febrero de 2.002 del Departamento de Industria, Comercio y DesarroIlo de la Comunidad de Aragón (BOCAr de 22 de febrero).

47 Vid. Orden de 30 de noviembre de 2.000 del Departamento de Industria, Comercio y Desarrollo de la Comunidad de Aragón (BOCAr de 29 de diciembre).
} 
comiendas suscritas con las CC.AA., y porque así lo permiten también las normas tributarias, de aplicación preferente en relación con el art. 15.5 LRJAPyPAC, por ser Ley especial en este caso (Disp. Adic. 5a LRJAPyPAC) ${ }^{48}$.

Por otra parte, si resulta fácilmente entendible que el sentido del apdo. 50 del art. 15 es el de evitar el fraude a los principios del TRLCCAAPP, no queda muy claro el significado del inciso final de ese mismo precepto. Allí se dice que no pueden "encomendarse a personas o Entidades de esta naturaleza (sujetas al Derecho Privado) actividades que, según la legislación vigente, hayan de realizarse con sujeción al Derecho Administrativo.". Parece querer decir que sólo caben las encomiendas de gestión (con la regulación del art. 15 LRJAPyPAC) a personas o empresas cuando se trate de actividades sujetas al Derecho Privado. Es decir, que se permite que una Administración negocie directamente, sin publicidad ni concurrencia, con un sujeto sometido al Derecho Privado la realización de una encomienda de gestión si el objeto de la misma es una actividad material, técnica o de servicios sometida también al Derecho Privado. Esto último es lo que no acertamos a entender, ya que, por definición, todos los encargos materiales, técnicos o de servicios que una Administración pueda hacer a un particular ( sea persona física o jurídica) estarán, de alguna u otra medida, sometidos a las leyes de contratación administrativas. La única interpretación razonable no absurda sería la de considerar que lo que la Ley está querien do decir es que sólo podrán celebrarse encomiendas de gestión con particulares o empresas cuando el ámbito objetivo de la misma pudiera ser susceptible de ser objeto de algunos de los negocios jurídicos excluidos de la Ley de Contratos por su art. 3, en particular, de los convenios de colaboración que, con arreglo a las normas específicas que los regulan, celebre la Administración con personas físicas o jurídicas sujetas al derecho privado, siempre que su objeto no esté comprendido en los contratos regulados en esta Ley o en normas administrativas especiales (art. 3.1,d) o de los contratos de arbitraje o conciliación (art. 3.1,j). Esto podría ser lógico si consideráramos que estos negocios han sido excluidos del ámbito objetivo de la Ley de Contratos por sujetarse al Derecho Privado, lo cual no es del todo cierto, ya que la mayoría de los convenios de colaboración que conocemos - en un principio celebrados casi siempre al margen de la ley -, se recogen ya en normas administrativas ( convenios urbanísticos, sanitarios, educativos, de presta-

${ }^{48} \mathrm{~A}$ mi juicio, su naturaleza cuasipública es lo que más claramente determina esa consecuencia, por encima del hecho de estar legitimadas en la legislación tributaria. Sus funciones registrales y tributarias están sometidas al Derecho Público, y poco afecta a la encomienda el que lo esté al Derecho Privado la organización de los medios materiales y personales de su trabajo. La visión contraria la exponen las SST de la Audiencia Nacional de 8 de marzo y de 31 de mayo de 1.999. 
ción de servicios sociales, cada vez más los ambientales, etc.). De esta forma, sólo nos quedarían los convenios arbitrales o de conciliación como única opción posible de convenios sujetos al Derecho Privado, esto es, a la Ley 36/ 1.988, de 5 de diciembre, que regula el Arbitraje de Derecho Privado, para la solución arbitral de conflictos de Derecho Privado. Se nos ocurre, por tanto, como ejemplo posible, aquella encomienda de gestión en la que una Administración encomendara a un árbitro la resolución de un litigio sobre lindes, propiedad o los efectos de un contrato privado con un particular. La encomienda sería posible según el art. 15.5 in fine, y se plasmaría en un convenio arbitral, como recoge el Título II de esa Ley.

\section{LA ENCOMIENDA DE GESTIÓN A FAVOR DE ENTIDADES LOCALES}

De profunda raigambre histórica, la encomienda de gestión en nuestro Derecho Local suponía la imposición obligatoria de cargas en las Entidades Locales por parte del Estado (tales como el reclutamiento de mozos o la custodia de detenidos) ${ }^{49}$. O bviamente, esta figura casa mal con la nueva regulación de tipo voluntario y consensuada que recoge el art. 15.4 LRJAPyPAC, de aplicación básica, desde 1.992, a las encomiendas de gestión celebradas entre el Estado y las CC.AA. con las Entidades Locales. El propio art. 4.4 de la LRJAPyPAC vuelve a incidir en la voluntariedad de las relaciones interadministrativas cuando dice que "Ia Administración General del Estado, las de las Comunidades Autónomas y las Entidades que integran la Administración Local deberán colaborar y auxiliarse para aquellas ejecuciones de sus actos que hayan de realizarse fuera de sus respectivos ámbitos territoriales de competencias.". También el art. 47.3,c) LRBRL obliga a que tenga que existir un consentimiento de la mayoría absoluta de los integrantes del Pleno para aceptar las encomiendas de gestión a realizar por las Administraciones superiores.

Salvo su apartado 4으, el resto del art. 15 LRJAPyPAC no tiene carácter básico para las EE.LL. cuando la encomienda de gestión se celebre entre el Estado o las CC.AA. con las Entidades Locales. El carácter especial del régimen local le hace prevalecer como fuente de primer grado en la regulación de todas las relaciones entre el Estado y las CC.AA. con las Entidades Locales. Así lo

${ }^{49} \mathrm{Cfr}$. PARADA, R., Régimen jurídico de las Administraciones Públicas y Procedimiento Administrativo Común / Estudio, comentarios y texto de la Ley 30/1992, de 26 de noviembre), Marcial Pons, MadridBarcelona, 1.999, págs. 116 y 117. 
proclama el art. 9 de la LRJAPyPAC, permitiendo la aplicación supletoria del Título I en defecto de la normativa de régimen local. Esto quiere decir que los límites y reglas explicadas hasta ahora sobre la encomienda de gestión sólo regirán con carácter básico en los Municipios, Diputaciones Provinciales, Mancomunidades, Áreas Metropolitanas, consorcios, etc. cuando se trate de encomiendas "intralocales", es decir, cuando tanto el encomendante como el encomendado sean órganos o entidades de carácter local o infraautonómico. Es decir, la entrada en vigor del art. 15 LRJAPyPAC supone que, en materia de encomiendas de gestión "intralocales" debe regir éste como derecho básico ${ }^{50}$.

En este apartado vamos a ver algunas especialidades de las encomiendas de gestión celebradas entre el Estado o las CC.AA. con las Entidades Locales, que, en lo básico, comparte la finalidad propia de las demás encomiendas de gestión vistas hasta ahora, y que no es otra que la plasmación del principio de eficacia de la actividad administrativa, pero que va más allá de ella en la medida en que consiste en ser un instrumento adecuado para la realización de la llamada descentralización administrativa, del principio de subsidiariedad o de la realización del actualmente conocido como "Pacto Local"51.

50 Así, el carácter básico de la Ley 30/ 1.992 parece indicar que no cabrían ya más encomiendas de gestión de la recaudación de tributos locales a las Diputaciones Provinciales que fueran más allá de permitir que éstas manejaran la llevanza y cobranza material de los tributos, como por ejemplo aquéllas en las que se encargara a éstas la realización de actuaciones formalizadas como el dictado de actos administrativos o el impulso de los procedimientos legales para la efectividad de la recaudación, tanto en período voluntario como ejecutivo, como se permitían antes de la Ley 30/ 1.992. Un ejemplo de extralimitación de estas encomiendas se contempla en la STS de 17 de enero de 1.998.

51 Tratar el tema del Pacto Local excedería con mucho del marco de esta investigación. Debe dejarse sentado, sin embargo, que las razones que han movido a la F.E.M.P. a reclamar desde principios de los noventa el aumento de competencias para las EE.LL. son absolutamente legítimas, ya que se estima que, actualmente, sólo un $14 \%$ del gasto público es gestionado por las EE.LL., en comparación con el $40 \%$ al que llegan países como Suecia o Dinamarca o del $20 \%$ en Alemania, Canadá, USA o Suiza. Vid. RODRÍGU EZ-ARANA, J., Pacto L ocal y R eforma Administrativa, pág. 71, en Jornadas sobre el Pacto Local, organizadas por el Gobierno de la Comunidad Foral de Navarra. Las actas y ponencias son accesibles por Internet en http:// www.cfnavarra.es/ info-local/ publicaciones/, accedida el 05 de mayo de 2.003. Por otra parte, tras la importante reforma operada ellas, sin duda alguna, la operada por la Ley 11/ 1999, de 21 de abril, dentro de las medidas para el desarrollo del Gobierno local, la Mesa del Congreso de los Diputados aprobó el pasado 13 de junio el Proyecto de Ley sobre Medidas para la Modernización del Gobierno Local, que, básicamente, incorpora a la LRBRL el nuevo régimen jurídico de los municipios de gran población, es decir, de aquéllos que superen los 250.000 habts., ó 200.000 si son capitales de provincia. 
La necesidad de descentralizar las competencias, en virtud del principio de subsidiariedad, se encuentra en numerosos preceptos de nuestro Ordenamiento jurídico, ya sea en normas generales (arts. 2.1 ó 28 LRBRL, 66-71 TR Disposiciones Vigentes en materia de régimen local ó 4.3. de la Carta Europea de Autonomía Local) o sectoriales (arts. 124.1 y 125 del Texto Refundido de la Ley de Aguas). Esta descentralización con base en la subsidiariedad tiene por finalidad acercar el ejercicio de las competencias a los ciudadanos, a la Administración menor, y en el ámbito local se contempla a través de la llamada "delegación" del ejercicio de competencias, institución en la que debemos incluir la técnica de la encomienda de gestión en sentido estricto, tal y como la hemos explicado desde el art. 15 LRJAPyPAC. En el caso de las EE.LL., la descentralización es una exigencia que la Ley impone al Estado y a las CC.AA., quienes deberán asegurar a los Municipios, las Provincias y las I slas su derecho a intervenir en cuantos asuntos afecten directamente al círculo de sus intereses, atribuyéndoles las competencias que procedan en atención a las características de la actividad pública de que se trate y a la capacidad de gestión de la entidad local, de conformidad con los principios de descentralización y de máxima proximidad de la gestión administrativa a los ciudadanos (art. 2 LRBRL). La importancia de este precepto es que establece una especie de "reserva normativa local", que impediría incluso a las Administraciones superiores "agotar" la regulación de sus competencias propias sin dejar ámbito de participación suficiente a lasEE.LL. Esta "invitación" puede bien hacerse mediante encomiendas, como recientemente ha reconocido el art. 4 de la Ley 3/ 2.003, de 11 de marzo, de la Comunidad de Madrid, para el Desarrollo del Pacto Local. Ese ámbito local de supervivencia permitiría que fuera el propio Ayuntamiento o Diputación el que se acercara a la Comunidad 0 al Estado para solicitarle la suscripción de una encomienda, aunque lo deseable sería que se hiciera de manera colectiva conforme al marco establecido en una Ley.

Además, cuando la encomienda supone una relación entre el Estado y las CC.AA. con las Entidades Locales, la autonomía funcional y orgánica de la que gozan éstas las exime de los estrictos límites objetivos de la encomienda que marca el art. 15 LRJAPyPAC. Efectivamente, los arts. 27 y 37 de la LRBRL regulan la encomienda de gestión a favor de los Municipios y Diputaciones Provinciales sin reducirse a las simples actividades materiales, técnicas o de servicios En los artículos citados, la encomienda de gestión se incluye dentro del ámbito material de la denominada "delegación", ya que ésta comprende cualquier encargo realizado a los Municipios y Provincias por las Comunidades Autónomas o por el Estado de ejercer determinadas competencias de su titularidad que se prefiere ceder en las Entidades Locales porque afectan a sus 
propios intereses, y siempre que con ello se mejore la eficacia de la gestión pública y se alcance una mayor participación ciudadana.

Aunque el régimen jurídico de estas delegaciones viene a ser muy similar al establecido en el art. 15 LRJAPyPAC, la importancia del principio democrático (que exige la mayor participación posible de los ciudadanos en el ejercicio de las funciones públicas, ex art. 9.2 (E), del de descentralización y del de subsidiariedad han suavizado el ámbito material de las mismas hasta el punto de permitir el encargo del ejercicio de actividades no estrictamente materiales sino formalizadas y sustantivas, que supongan el ejercicio de potestades o el dictado de actos administrativos. En esa misma línea, a diferencia del régimen de la encomienda básica, el art. 27 LRBRL (cuyas prescripciones rigen subsidiariamente también para el 37 LRBRL, como proclama su apartado 3의 obliga a las Administraciones superiores a transferir junto con la encomienda los medios personales, materiales y económicos necesarios para su realización plena. No obstante, como contrapartida a este mayor ámbito objetivo y como consecuencia del lastre histórico de control y subordinación de las Entidades Locales, el propio art. 27.2 permite (no exige, puesto que esto sería contrario al principio de autonomía local) al particular afectado por el ejercicio de la encomienda o delegación poder impugnar los actos del Municipio o Diputación directamente ante la Administración delegante, a diferencia de lo que vimos que pasaba en el control de la encomienda del art. 15 LRJAPyPAC, donde el control de los actos se realiza directamente ante el encomendero o el encomendante.

No resulta difícil encajar las encomiendas de gestión a favor de las Entidades Locales en el contexto del art. 57 de la LRBRL, en el que se deriva a la libre voluntad de las partes todas las relaciones de auxilio, técnicas 0 administrativas que puedan tener éstas con el Estado y las CC.AA. Atrás quedaron ya las épocas de imposición o de cargas forzosas, de manera que el marco normal de encuentro entre estas partes habrá de ser siempre la cooperación, como señala este precepto, y su plasmación ordinaria los convenios administrativos. Tal vez sea por ello por lo que HERNANDO OREJANA resalta certeramente en su monografía sobre la encomienda de gestión que este tipo de convenios interadministrativos implica la imposibilidad de que ninguna de la partes pueda imponer cláusulas exorbitantes a la otra en el convenio, puesto que a nivel interadministrativo la institución tiene un carácter más organizativo del ejercicio de competencias que de paliativo de la carencia de medios del encomendante ${ }^{52}$.

52 Cfr. HERNANDO OREJANA, L. C., La Encomienda de Gestión, opus cit., pág. 138, para quien "El reconocimiento explícito de la paridad de las partes intervinientes supone la quiebra del modelo autoritario de relaciones interadministrativas en las que el ente superior imponía su autori- 
Tal vez la diferencia fundamental de la encomienda a favor de las EE.LL. y el resto de encomiendas de gestión se cifra en que en este nivel las competencias ejercidas por el encomendero tienen una clara finalidad de producir efectos jurídicos ad extra, es decir, de cara a los vecinos y ciudadanos, en contra del carácter puramente interno de los efectos y consecuencias de las encomiendas inter o intra estatales y autonómicas, en las que la exteriorización de la actividad siempre la lleva a cabo el ente encomendante. Es más, es esa y no otra la finalidad de la figura a escala local.

Y por esa misma razón, la causa que motiva o puede mover a la encomienda a una Comunidad Autónoma o al Estado no es su carencia o insuficiencia de medios técnicos, materiales o serviciales, sino otro parámetro de la eficacia administrativa cual es la mayor proximidad geográfica de la actuación administrativa al domicilio del ciudadano $0^{53}$ y, por ende, la mayor participación ${ }^{54}$ de éste en las políticas locales ${ }^{55}$.

dad a través de las distintas técnicas previstas en el ordenamiento jurídico, fundamentalmente las de control y tutela, propias de un Estado de corte centralista". H emos encontrado un ejemplo de ello en la ya citada encomienda celebrada entre los Departamentos de Presidencia e Interior de la Comunidad Foral de Navarra y el Ministerio del Interior para la realización de las actividades técnica relacionadas con la competencia en materia de juegos propia de la Comunidad, en convenio suscrito entre ambas y plasmado en Resolución de la Secretaría General Técnica del Ministerio del Interior de 14 de julio de 1.998. Allí tanto el control como la resolución de dudas o la integración de lagunas de la encomienda se realiza de manera conjunta entre las dos partes.

53 El acercamiento tiene que ser de la Administración al ciudadano, sin que ello implique necesariamente que sea necesario descentralizar en otra Administración Pública (aunque esto sea lo normal), bastando a veces la desconcentración. Así sucedió en la encomienda celebrada entre los Ministerio de Economía y Hacienda y el Ministerio de Administraciones Públicas para la cesión a éste y, en concreto a la Directora insular de la Administración General del Estado en la isla de La Palma, de la gestión material de los certificados de importación, de exención y de ayuda contemplados e el Reglamento (CE) 2.790/94, de 16 de noviembre, dada la inexistencia de organismo de la Administración comercial en la isla de La Palma. Vid. la Resolución de la Subsecretaría del Ministerio de la Presidencia de 4 de mayo de 1.998 (B.O.E. de 5 de mayo). Por razones parecidas la Agencia Española de Cooperación Internacional encomendó al Cónsul General de España en Córdoba (Argentina) para formar parte del Centro Cultural de España en esa ciudad, en la que la A.E.C.I. carecía de instalaciones. Vid. Resolución de la A.E.C.I. de 12 de septiembre de 1.997 (B.O.E. de 7 de noviembre). A veces se emplean técnicas de descentralización y desconcentración juntas, como en el caso de Orden de 30 de julio de 1.999 de la Consejería de Salud de la Junta de Andalucía (BOJA de 19 de agosto), por la que la Consejería delegaba en sus Delegaciones Provinciales la competencia para celebrar convenios de encomienda de gestión con Ayuntamientos para la tramitación de los procedimientos sancionadores en materia de salud pública cuya resolución correspondiera a los Alcaldes.

${ }^{54}$ Como ya he tenido ocasión de decir otras veces, la participación de los ciudadanos en los asuntos públicos es un fin en sí mismo y un bien jurídico a proteger con independencia, incluso, 
Todas las características señaladas hacen que la delegación del ejercicio de competencias de los arts. 27 y 37 LRBRL sean instituciones más adecuadas que la propia encomienda de gestión a efectos de corregir el escaso índice de descentralización administrativa existente en España, tarea demasiado ambiciosa que requiere un instrumento de mayor amplitud objetiva y calado formal que la encomienda del art. 15.4 LRJAPyPAC, limitada a otro tipo de descentralización más puntual.

de la mayor o menor eficacia de la actividad administrativa en la que dicha participación se inserte. Ésta y no otra es, a mi juicio, la esencia de la democracia. Lo contrario equivaldría a consagrar como valor supremo la "eficacia administrativa" de la actuación de las Administraciones sin ciudadanos, esa especie de tecnocracia administrativa, de despotismo ilustrado de las Administraciones. El poder sin la participación directa y el control de los ciudadanos se deslegitima. De ahí también el juego del principio democrático como elemento desencadenante del principio de subsidiariedad, entendido como descentralización estatal o autonómica a favor de las EE.LL.

55 Son muchas las encomiendas de gestión celebradas a favor de EE.LL. con finalidad descentralizadora, como la que perfeccionaron la Delegaciones Provincial en Cádiz de la Consejería de Turismo y Deporte de la Junta de Andalucía y la Subdelegación del Gobierno de la Junta de Andalucía en el Campo de Gibraltar para encargar a ésta la ejecución de algunas de sus competencias "con el objetivo de acercar la actuación de los órganos administrativos a los ciudadanos, mejorando la eficacia en la prestación de los servicios públicos". Este caso muestra, además, que las encomiendas de gestión entre órganos estatales o autonómicos también pueden tener efectos ad extra, hacia los ciudadanos, y no puramente internos entre las partes de la encomienda. 